\title{
Area and volume loss of the glaciers in the Ortles-Cevedale group (Eastern Italian Alps): controls and imbalance of the remaining glaciers
}

\author{
L. Carturan ${ }^{1}$, R. Filippi ${ }^{2,3,4, \dagger}$, R. Seppi ${ }^{5}$, P. Gabrielli ${ }^{3,6}$, C. Notarnicola ${ }^{2}$, L. Bertoldi ${ }^{7}$, F. Paul ${ }^{8}$, P. Rastner $^{8}$, \\ F. Cazorzi ${ }^{9}$, R. Dinale ${ }^{10}$, and G. Dalla Fontana ${ }^{1}$ \\ ${ }^{1}$ Department of Land, Environment, Agriculture and Forestry, University of Padova, Agripolis, Viale dell'Università 16, \\ 35020 Legnaro, Padova, Italy \\ ${ }^{2}$ Institute for Applied Remote Sensing, EURAC, Viale Druso 1, 39100 Bolzano, Italy \\ ${ }^{3}$ Byrd Polar Research Center, The Ohio State University, 108 Scott Hall, 1090 Carmack Road, Columbus, Ohio 43210-1002, \\ USA \\ ${ }^{4}$ Museo delle Scienze, Via Calepina 14, 38122, Trento, Italy \\ ${ }^{5}$ Department of Earth and Environmental Sciences, University of Pavia, Via Ferrata 1, 27100, Pavia, Italy \\ ${ }^{6}$ School of Earth Science, The Ohio State University, 275 Mendenhall Laboratory, 125 South Oval Mall, Columbus, Ohio \\ 43210, USA \\ ${ }^{7}$ Chartagena, aerial analysis, Via Maccani 211, 38121, Trento, Italy \\ ${ }^{8}$ Department of Geography, University of Zurich, Winterthurerstr. 190, 8057 Zurich, Switzerland \\ ${ }^{9}$ Department of Agriculture and Environmental Science, University of Udine, Via delle Scienze 208, 33100 Udine, Italy \\ ${ }^{10}$ Ufficio Idrografico - Provincia Autonoma di Bolzano, Via Mendola 33, 39100 Bolzano, Italy \\ $\dagger$ deceased
}

Correspondence to: L. Carturan (luca.carturan@unipd.it)

Received: 14 November 2012 - Published in The Cryosphere Discuss.: 21 January 2013

Revised: 10 July 2013 - Accepted: 27 July 2013 - Published: 2 September 2013

\begin{abstract}
A widespread loss of glacier area and volume has been observed in the European Alps since the 1980s. In addition to differences among various regions of the Alps, different responses to climate change characterize neighboring glaciers within the same region. In this study we describe the glacier changes in the Ortles-Cevedale group, the largest glacierized area in the Italian Alps. We analyze the spatial variability, the drivers, and the main factors controlling the current loss of ice in this region, by comparing mean elevation changes derived from two digital terrain models (DTMs), along with glacier extents and snowcovered areas derived from Landsat images acquired in 1987 and 2009, to various topographic factors. Glacier outlines were obtained using the band ratio method with manual corrections. Snow was classified from a near-infrared image after topographic correction. The total glacierized area shrank by $23.4 \pm 3 \%$ in this period, with no significant changes in the mean altitude of the glaciers. In 2009 the snow-
\end{abstract}

line was $240 \mathrm{~m}$ higher than in the 1960s and 1970s. From the snow-covered area at the end of summer 2009, which fairly represents the extent and local variability of the accumulation areas in the 2000s, we estimate that approximately $50 \%$ of the remaining glacier surfaces have to melt away to re-establish balanced mass budgets with present climatic conditions. The average geodetic mass budget rate, calculated for 112 ice bodies by differencing two DTMs, ranged from $-0.18 \pm 0.04$ to $-1.43 \pm 0.09 \mathrm{~m}^{-e .} \mathrm{a}^{-1}$, averaging $-0.69 \pm 0.12 \mathrm{~m}$ w.e. $\mathrm{a}^{-1}$. The correlation analysis of mass budgets vs. topographic variables emphasized the important role of hypsometry in controlling the area and volume loss of larger glaciers, whereas a higher variability characterizes smaller glaciers, which is likely due to the higher importance of local topo-climatic conditions. 


\section{Introduction}

The response of glaciers to climatic fluctuations is primarily controlled by their geographic setting, in particular by their latitude and prevailing climatic conditions (wet/maritime to dry/continental). In general, glaciers are more sensitive to climate change in maritime regions with high precipitation and mass turnover (Oerlemans, 2001; Hoelzle et al., 2003; De Would and Hock, 2005; Benn and Evans, 2010).

However, local topographic and microclimatic conditions determine the behavior of glaciers at smaller scales, for example within a mountain group. Thus, different behaviors can be observed among neighboring glaciers in response to the same climatic forcing (e.g., Kuhn et al., 1985). These differences mainly depend on the geometry of the glaciers (hypsometric distribution of area vs. altitude, size, slope, aspect), but are also related to the physical characteristics of the surrounding terrain, source of nourishment and debris coverage, which control the local energy and mass balance (Furbish and Andrews, 1984; Benn and Lehmkuhl, 2000; Machguth et al., 2006; Chueca et al., 2007). In addition, feedbacks such as albedo lowering and geometric changes, like surface lowering and disintegration, affecting radiative and sensible heat fluxes (Paul et al., 2005; Raymond et al., 2005; Carturan and Seppi, 2007; Oerlemans et al., 2009; Paul, 2010; Carturan et al, 2012b), influence the reaction of individual glaciers to climate fluctuations.

The highly variable and interdependent response of glaciers to climate change, involving changes in length, area, thickness and flow velocity, complicates the assessment of future glacier behavior under different climate change scenarios. Nevertheless, studying the spatial variability of glacier fluctuations and their relationship to topographic factors and climatic change can be seen as a good opportunity to improve our knowledge about processes and feedbacks in action. Moreover, such an analysis is a valuable tool for quantifying disequilibrium between current glacier geometries and those expected under the current climate conditions (e.g., Pelto, 2006).

The most immediate indication of the degree of disequilibrium of glaciers is their mass balance evolution. Generally, a few glaciers with suitable characteristics in terms of size and accessibility are monitored with the "direct" method (Østrem and Brugman, 1991; Kaser et al., 2003; Cogley et al., 2011), but their representativeness for entire regions or mountain ranges is often unknown. Hence, the extrapolation of measured mass balances to nearby glaciers is challenging, because local characteristics affect the mass and energy fluxes on individual glaciers (Carturan et al., 2009a; Fountain et al., 2009; Kuhn et al., 2009).

Other variables closely related to the mass balance, such as the equilibrium line altitude (ELA) and the accumulation area ratio (AAR, the ratio between the accumulation area and total area), can be used to assess the direct impact of climate change (e.g., an upward shift of the ELA) or the degree of im- balance of glaciers with respect to current climate conditions, such as the deviation of AAR from a balanced-budget AAR (Bahr et al., 2009). However, the relationship with mass balance is not univocal, particularly in high-mountain environments, where avalanches, debris cover and topographic shading can strongly affect the spatial distribution of the mass balance (e.g., Braithwaite, 1984; Kulkarni, 1992; Clark et al., 1994; Benn and Lehmkuhl, 2000; Zemp et al., 2008; Braithwaite and Raper, 2009).

Measuring mass balance by means of the geodetic method increases the spatial coverage (Cogley, 2009) and provides the total volume change also considering processes not measured at the surface, like the basal melting, and regions that are not assessed, like steep parts or zones with seracs. The geodetic method is thus used to calibrate field measurements (e.g., Thibert et al., 2008; Haug et al., 2009; Huss et al., 2009; Zemp et al., 2010), but doing this accurately can be rather demanding, for example due to the unknown densities of firn and snow (Fischer, 2011; Huss, 2013; Zemp et al., 2013). The geodetic method can also be used to assess the representativeness of the measured glaciers for the mass budget of entire mountain ranges and to analyze the spatial pattern of glacier thickness changes over large regions (Dyurgerov and Meier, 2005; Haeberli et al., 2007; Paul and Haeberli, 2008). The modern tool for such assessments is the multi-temporal differencing of digital terrain models (DTMs), which has recently been improved in terms of accuracy, automation and resolution by airborne laser scanning using LiDAR (light detection and ranging) technology (e.g., Arnold et al., 2006; Geist and Stötter, 2007; Knoll and Kerschner, 2009; Joerg et al., 2012). The dependence of the observed glacier fluctuations on local variables (e.g., topographic attributes) can be investigated by means of statistical analyses to assess why different glaciers react in different ways to the same climatic forcing (e.g., Chueca et al., 2007; Abermann et al., 2009 and 2011; Vanlooy and Forster; 2011).

Since the 1980s, the European Alps have experienced a phase of intense glacier area and volume loss, which has also been observed worldwide (Kaser et al., 2006; UNEP/WGMS, 2008; WGMS, 2008). Regional-scale analyses of this recession period in the Alps have been carried out by several authors, who focused mainly on area and length changes using multi-temporal remotely sensed data and existing ground measurement series (e.g., Paul et al., 2004 and 2007a; Lambrecht and Kuhn, 2007; Citterio et al., 2007; Zemp et al., 2008). The spatial variability of glacier elevation changes from DTM differencing was analyzed in fewer studies, mainly in Switzerland (Paul and Haeberli, 2008) and in Austria (Abermann et al., 2009). Regional assessments of glacier area and length changes in the Italian Alps over this period were carried out in the Lombardia region (Maragno et al., 2009; Diolaiuti et al., 2011) and Aosta valley (Diolaiuti et al., 2012). In South Tyrol, Knoll and Kerschner (2009) also analyzed volume changes. 
In this work, we use two Landsat scenes from 1987 and 2009 and two DTMs acquired in the 1980s and 2000s to quantify changes in glacier length, area and volume over the entire range of the Ortles-Cevedale group, the largest Italian glacierized mountain range, located in the Eastern Alps. We examine topographic parameters, their changes through time and their possible role in controlling the spatial variability of glacier changes. We also quantify the current disequilibrium of glacier extents by comparing AARs to a mean balancedbudget value of the $\mathrm{AAR}\left(\mathrm{AAR}_{0}\right)$. The analysis is also aimed at providing an environmental context for the recently undertaken paleo-climatological investigations on Mt. Ortles (Gabrielli et al., 2010 and 2012; Gabrieli et al., 2011).

\section{Study area and data sets}

\subsection{Study area}

The Ortles-Cevedale group is located in the Eastern Italian Alps and covers an area of $1638 \mathrm{~km}^{2}$ (Fig. 1). The highest peaks of this mountain group, Mt. Ortles (3905 m), Mt. Gran Zebrù $(3851 \mathrm{~m})$ and Mt. Cevedale $(3769 \mathrm{~m})$, are aligned in a NW-SE direction. Rather sharp ridges exist in the northwestern area, which is composed of sedimentary rocks (dolomites and limestones), whereas metamorphic rocks (mica schists, paragneiss and phyllites) prevail elsewhere, forming more rounded reliefs. These lithologic differences have an important influence on the terrain morphology and significantly affect the distribution and morphology of the glaciers (Desio, 1967).

The glaciers of the Ortles-Cevedale constitute a major resource for the local population, because they have a great touristic appeal and are precious water resources. The mountain group is one of the largest glacierized regions of the southern side of the European Alps $\left(76.8 \mathrm{~km}^{2}\right.$, approximately $3.5 \%$ of the total Alpine glacierized area) and hosts the largest Italian valley glacier (Forni, $11.3 \mathrm{~km}^{2}$ ). Like most of the glaciers in the European Alps, the Ortles-Cevedale glaciers have been retreating since the end of the Little Ice Age (LIA), with phases of temporary re-advance in the 1890s, 1910-20s and in the 1970-1980s. A new phase of strong retreat began in the second half of the 1980s and is still continuing (Citterio et al., 2007; CGI, 1978-2011, Zemp et al., 2008).

The Ortles-Cevedale group lies in a transition zone between the "inner dry alpine zone" to the north (Frei and Schär, 1998) and the wetter area under the influence of the Mediterranean Sea to the south. Figure 2 shows the monthly regime of average temperature and precipitation at the Careser dam weather station (2605 m a.s.1.), which is located in the southern part of the study area (Fig. 1). In the valleys, the annual precipitation ranges from $\sim 900 \mathrm{~mm}$ at the southern edge of the group to $\sim 500 \mathrm{~mm}$ at the northern edge. Precipitation increases with altitude, up to values of
1300-1500 $\mathrm{mm} \mathrm{a}^{-1}$ at 3000-3200 $\mathrm{m}$ within the glacierized areas of the group (Carturan, 2010; Carturan et al., 2012a). The mean annual $0{ }^{\circ} \mathrm{C}$ isotherm is located at approximately $2500 \mathrm{~m}$.

\subsection{Data sets}

Two early-autumn Landsat scenes (path 193, row 28 from 20 September 1987 and 31 August 2009; downloaded from http://glovis.usgs.gov) were selected to map glacier extents and snow cover, based on the absence of fresh snow and the presence of very low cloud cover $(\sim 1 \%$ ). The DTMs were acquired between 1981 and 1984 and between 2005 and 2007, with different methods and spatial resolutions by the local administrations of the Ortles-Cevedale group (Table 1). Printed aerial photos (black and white, scale 1: 10000 to $1: 20000$, years 1982 and 1983) and digital orthophotos (colors, resolution $0.5 \times 0.5 \mathrm{~m}$, years 2006-2008) were also available. For simplification, hereafter we refer to the $1980 \mathrm{~s}$ and 2000s as the beginning and end of the investigated period.

The longest time series of direct mass balance measurements in the Ortles Cevedale group is available for the Careser glacier and started in 1967 (Zanon, 1992; Carturan and Seppi, 2007; WGMS, 2011). Other much shorter mass balance series in this group exist for the Fontana Bianca glacier (1984-1988, restarted in 1992) and the Sforzellina glacier (since 1987) (CGI, 1978-2011; WGMS, 2008; C. Smiraglia, personal communication). Mass balance investigations were also started in 2003 on the La Mare glacier (Carturan et al, 2009b; Fig. 3) and in 2004 on the Vedretta Lunga glacier (WGMS, 2008).

A long series of meteorological data at high altitude exists for the Careser dam weather station, since 1930, which provides additional information for interpreting the observed glacier changes. Observations used in this study include daily precipitation, $2 \mathrm{~m}$ air temperature and snow observations (fresh snow and total snow depth) over the period 19592009.

\section{Methods}

\subsection{Calculation of glacier area and length changes}

Two glacier inventories, including 165 glacier basins in the Ortles-Cevedale group, were created from the two Landsat images, to calculate area changes between the 1980s and the 2000s. The Landsat scenes, whose orthorectification was checked against the DTMs of the 2000s (Table 1), were processed using the ESRI ArcGIS software, in the UTMWGS84 (Universal Transverse Mercator, zone 32, World Geodetic System 1984 datum) coordinate system. A thresholded band ratio image, given by the Landsat visible band TM3 divided by the shortwave infrared band TM5, was used for classifying the debris-free areas of glaciers (e.g., Paul and 


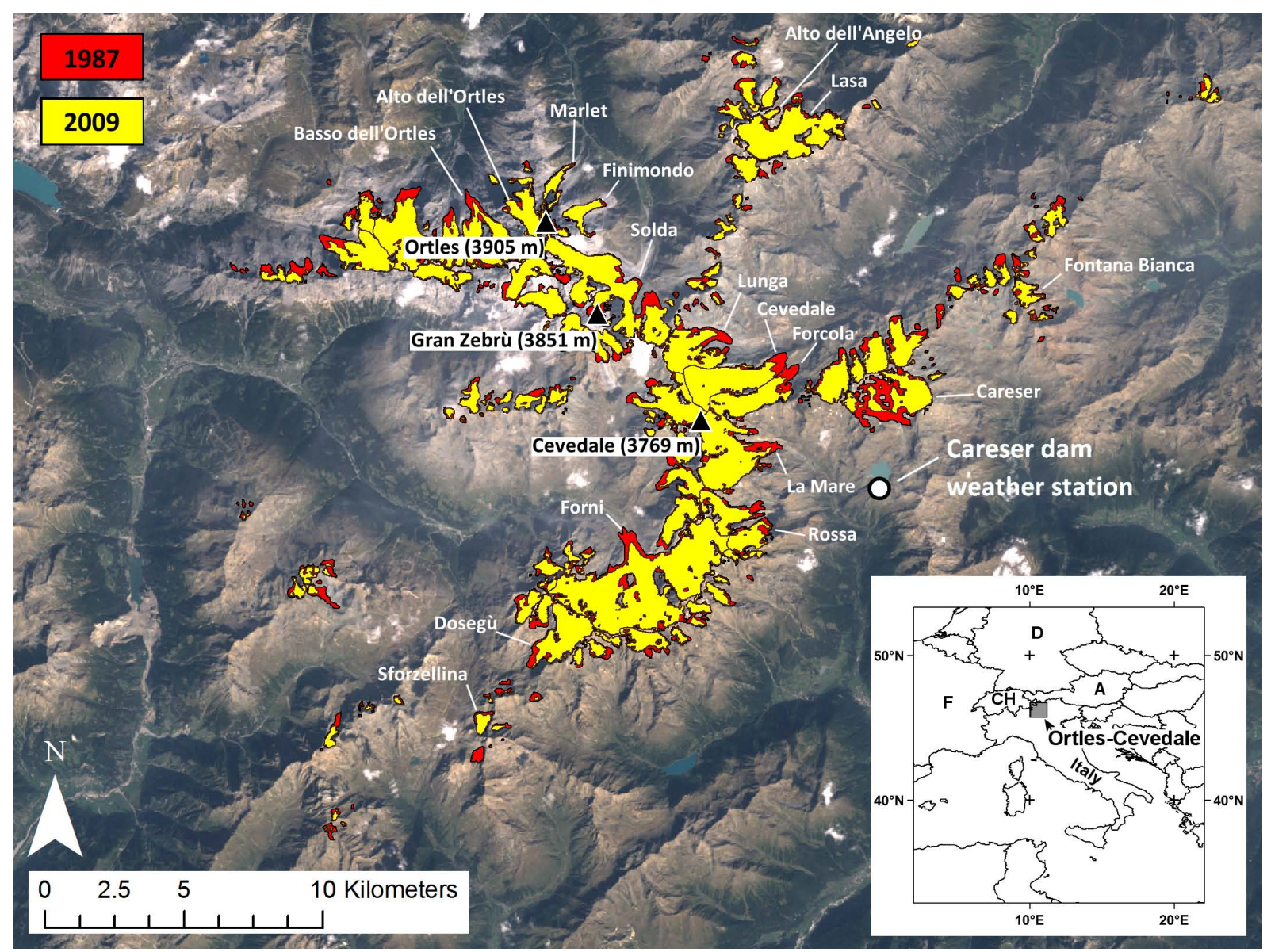

Fig. 1. Geographic setting of the Ortles-Cevedale group with glacier extents from 1987 and 2009. Named glaciers are referred to in the text.

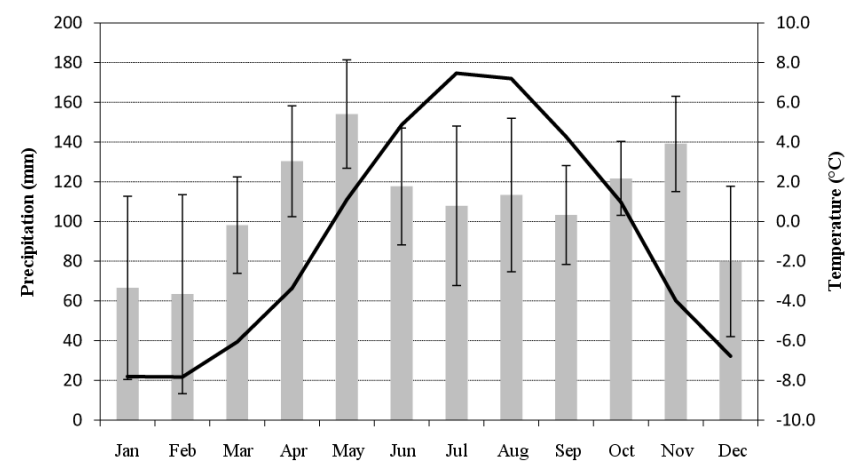

Fig. 2. Monthly air temperature (line) and precipitation (histogram) at the Careser dam weather station (2605 $\mathrm{m}$ a.s.1.), averaged over the period 1959-2009. Bars on histogram indicate one standard deviation.

Kääb, 2005; Andreassen et al., 2008; Paul et al., 2011). Optimization of threshold values and manual post-processing, required to remove inclusion of lakes, and for correcting misclassifications over shadowed and debris-covered areas, were carried out using contrast-enhanced composites of Landsat scenes (bands 5, 4 and 3 as red, green and blue, respectively) and aerial photos. In a few cases, a direct geomorphological inspection in the field was performed in late summer of 2010 , to determine the lower boundary of currently debris-covered glaciers. In 1987, the margins were more evident in the satellite imagery due to more limited debris cover and more convex and sharp fronts. In many cases, frontal moraines that were visible in the 2000 s aerial photos (e.g., Fig. 4) were helpful for correcting the automatic classification of debriscovered fronts in 1987, because these moraines mark the most advanced position of the glaciers during the mid-1980s (CGI, 1978-2011). For the limited areas covered by clouds in the Landsat scenes (less than $1 \%$ of the total glacierized area), we reconstructed the glacier outlines using aerial photos and the closest in time Landsat image available.

The identification of glacier units was based on former inventories. We mainly used the World Glacier Inventory (WGMS, 1989), adding two small units (Alto del Marlet and Cima della Miniera) that were reported in previous works (CNR-CGI, 1959-1962; Desio, 1967). The divides of the drainage basins were derived from a flow direction grid calculated from the most recent DTMs, which have higher 

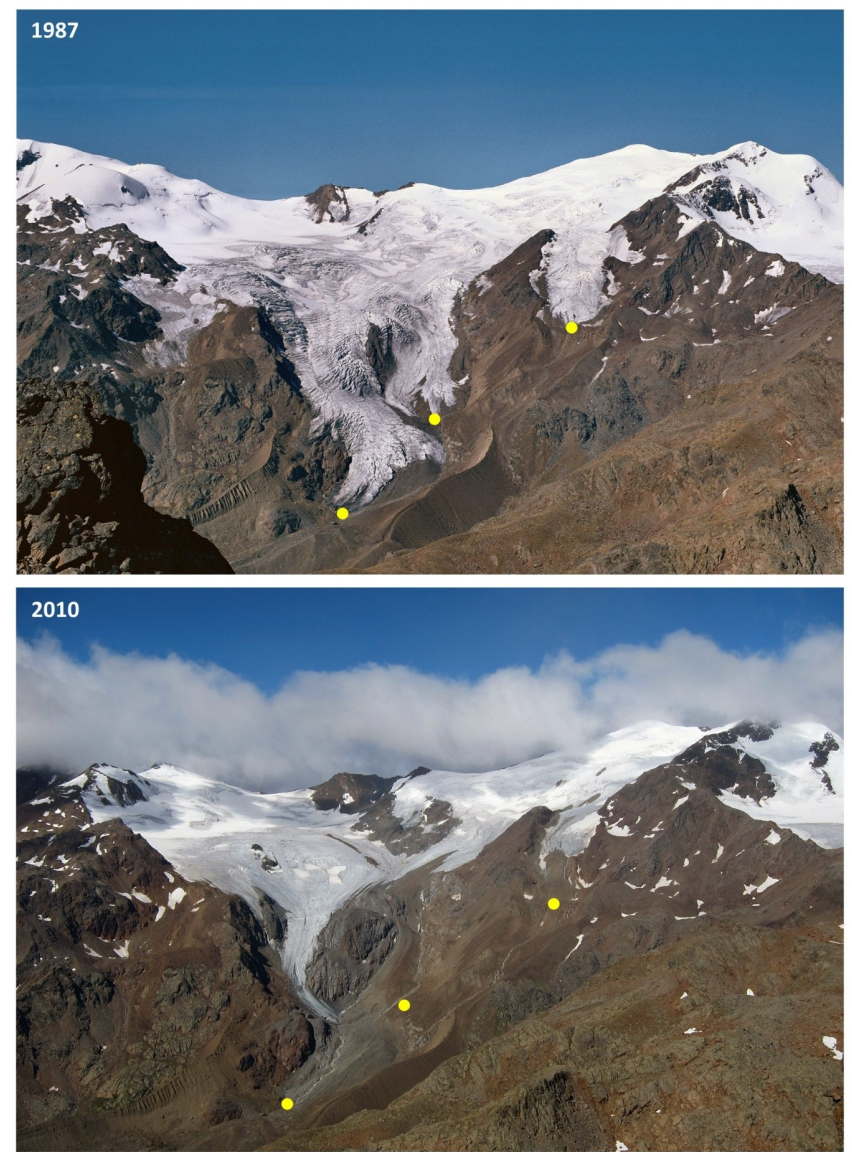

Fig. 3. Example of the current shrinking of glaciers in the OrtlesCevedale group. Repeat photography of La Mare glacier in late summer 1987 (photo Giuliano Bernardi, http://www.fotobernardi.it) and on 28 August 2010 (photo L. Carturan). The yellow circles indicate corresponding points in both photos.

spatial resolution than the DTMs acquired in the 1980s (Table 1). The classified grids with two surface types (debrisfree and debris-covered areas), which were obtained from each Landsat scene after manual editing, were converted to polygon shapefiles and then intersected with the shapefile of the digitized drainage basins. For each drainage basin, the total glacierized area was calculated as the sum of the areas of the two surface types.

The minimum size for an ice body was set at $0.01 \mathrm{~km}^{2}$, and topographic parameters for each ice body were calculated from the DTMs of the two periods according to Paul et al. (2009), extracting minimum, maximum and mean values from the grids of elevation, slope, aspect, and clear-sky global radiation in summer (June to September). The latter was calculated using the Solar Radiation Tools implemented in ArcGIS Spatial Analyst (Dubayah and Rich, 1995). The calculations account for atmospheric effects, site latitude and elevation, slope and aspect, daily and seasonal shifts of the sun angle, and the effects of shadows cast by surrounding to-

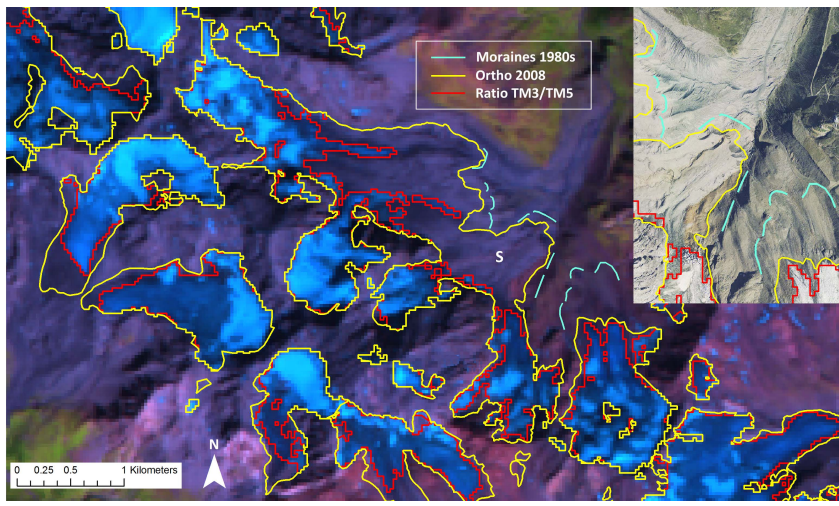

Fig. 4. Comparison of the automatic delineation of Solda glacier (S) from the thresholded band ratio image of 31 August 2009 (TM3/TM5; RGB composite of bands 5, 4, and 3 in the background) and post-processed delineation from aerial orthophoto (ortho 2008, in the inset). Lateral and terminal moraines built by this glacier in the mid-1980s (in light blue) were used for post-processing the automatic delineation from the 1987 Landsat image.

pography. The average elevation used in the analyses is the "area-averaged" elevation of each glacier. Because aspect is a circular parameter, the mean value for each glacier was calculated as the arc tangent from the respective mean values of the sine and cosine grids of terrain aspect (Manley, 2008; Paul et al., 2009). We made the assumption that the glacier changes that occurred between the acquisition dates of the DTMs (Table 1) and the respective Landsat scenes were negligible in comparison to the total changes that occurred between the 1980s and the 2000s.

\subsection{Calculation of glacier volume changes and average mass budget}

Before calculating the elevation changes of the glaciers, all the DTMs were resampled to a grid cell size of $20 \mathrm{~m}$ (i.e., the maximum cell size of the original DTMs, Table 1). They were then co-registered and checked for possible elevationor slope-dependent biases (Berthier et al., 2006; Paul, 2008; Gardelle et al., 2012a). The results showed no clear dependencies of the elevation differences between the DTMs on elevation or slope over stable terrain. Therefore, we did not apply any correction to the elevation difference grid calculated from the co-registered DTMs (see Section 4.2 for considerations on the accuracy). The total volume change $\Delta V$ $\left(\mathrm{m}^{3}\right)$ for each glacier was calculated as

$\Delta V=\bar{\Delta} z \cdot A_{1987}$,

where $\bar{\Delta} z$ is the average elevation change between the $\mathrm{DTM}_{2000}$ and DTM 1980 over the area $A_{1987}$, which was assumed to be the largest in the investigated period. The areaaveraged specific geodetic mass budget rate $\left(\mathrm{m}\right.$ w.e. $\left.\mathrm{a}^{-1}\right)$, referred to as "average mass budget" hereafter, was calculated as 
Table 1. Characteristics of the digital terrain models available for the Ortles-Cevedale group.

\begin{tabular}{|c|c|c|c|c|c|c|c|}
\hline \multirow[b]{2}{*}{ Province } & \multirow[b]{2}{*}{$\begin{array}{c}\text { Time } \\
\text { interval } \\
\text { (years) }\end{array}$} & \multicolumn{3}{|c|}{ DTM 1980s } & \multicolumn{3}{|c|}{ DTM 2000s } \\
\hline & & $\begin{array}{l}\text { Acquisition } \\
\text { date }\end{array}$ & $\begin{array}{l}\text { Cell } \\
\text { size } \\
(\mathrm{m})\end{array}$ & Method & $\begin{array}{l}\text { Acquisition } \\
\text { date }\end{array}$ & $\begin{array}{l}\text { Cell } \\
\text { size } \\
(\mathrm{m})\end{array}$ & Method \\
\hline $\begin{array}{l}\text { Sondrio and } \\
\text { Brescia }\end{array}$ & 26 & 19-08-1981 & 20 & $\begin{array}{l}\text { Aerial } \\
\text { photogrammetry }\end{array}$ & $\begin{array}{l}\text { Late summer } \\
2007\end{array}$ & 5 & $\begin{array}{l}\text { Aerial } \\
\text { photogrammetry }\end{array}$ \\
\hline Trento & 23 & 24-09-1983 & 10 & $\begin{array}{l}\text { Aerial } \\
\text { photogrammetry }\end{array}$ & October 2006 & 2 & LiDAR \\
\hline Bolzano & 21 & $\begin{array}{l}\text { Late summer } \\
1984\end{array}$ & 20 & $\begin{array}{l}\text { Aerial } \\
\text { photogrammetry }\end{array}$ & $\begin{array}{l}\text { Late summer } \\
2005\end{array}$ & 2.5 & LiDAR \\
\hline
\end{tabular}

$\dot{M}=\frac{\Delta V \cdot \rho}{\bar{A}} \cdot t^{-1}$,

where $\rho$ is the mean density, $\bar{A}$ is the average of the $A_{1987}$ and $A_{2009}$ areas, and $t$ is the time interval (in years) between the two periods. We used a mean density of $850 \mathrm{~kg} \mathrm{~m}^{-3}$, rather than $900 \mathrm{~kg} \mathrm{~m}^{-3}$, as suggested in the literature for glaciers that are thinning and losing old firn at mid-elevation areas (Krimmel, 1989; Sapiano et al., 1998; Elsberg et al., 2001; Fischer, 2011).

\subsection{Extent of accumulation areas and current degree of imbalance}

Useful information on the extent of accumulation areas was derived from the two Landsat scenes by assuming that the late-summer snow-covered area (SCA) is identical with the accumulation region. While this is not always correct, other studies have shown that it is however a reasonable approximation (e.g., Rabatel et al., 2008). On both acquisition dates, the snowline was well defined and the SCA was very close to its annual minimum. Indeed, according to the meteorological observations of the Careser dam personnel, the 1987 scene was acquired at the end of the ablation season, after a two-week period of warm and dry weather, right before the first snowfall event of the following accumulation season on 24 September. According to our observations on $\mathrm{La}$ Mare glacier, the 2009 scene was acquired shortly before the end of the ablation season, with the SCA on August 31 $\left(0.77 \mathrm{~km}^{2}\right)$ being only $11 \%$ larger than its minimum value $\left(0.69 \mathrm{~km}^{2}\right)$ in mid-September. The accumulation areas visible in the Landsat scenes are also fairly representative of their long-term extent. In particular, the scene from 2009 has AARs close to the average of the preceding decade (Table 2). In addition, the two series of direct observations available for the Ortles-Cevedale group on Careser and Fontana Bianca glaciers show that the average AAR in the period between 1987 and 2009 ( 0.01 and 0.10 , respectively) is within the range of the arithmetic mean values of the AAR derived from the two Landsat scenes ( 0.01 and 0.22 , respectively).
The SCA was mapped based on differences in reflectance in the near-infrared band of the Landsat scenes (TM4, 0.76$0.90 \mu \mathrm{m})$. We applied the procedure described in Bippus (2011) for converting the digital numbers to at-satellite radiance and for deriving the top-of-atmosphere reflectance (TOAR), accounting for the Sun-Earth distance, the spectral top-of-atmosphere solar irradiance and the solar zenith angle. Afterwards, a radiometric correction for topographic effects was applied to the TOAR to account for slope and aspect effects on the surface irradiance (different contributions of direct and diffuse irradiance). We tested the Minnaert and Ekstrand correction methods for this process (Minnaert, 1941; Ekstrand, 1996), which are both suitable for steep alpine terrain (Law and Nichol, 2004; Törmä and Härmä, 2003; Ekstrand, 1996). In comparison with false-color composites the Ekstrand method provided the best results and was selected for the corrections.

The maps of the corrected TOAR were converted with a threshold for discriminating snow-covered and snow-free areas. This was straightforward because snow showed a very different reflectance compared to ice and firn in both scenes (see Fig. 5). In 2009, field data were available to check the thresholds, whereas in 1987 there were no direct observations and we adjusted the thresholds by comparing automatic classifications with a contrast-enhanced false-color composite image, using TM bands 4, 3 and 2 as RGB in sunlight and bands 3,2 and 1 in shadow.

The SCA and the snowline altitude (SA) from the 1987 and 2009 images were examined for eight aspect classes. The SA position was determined by intersecting the lower limit of the SCA with the respective DTM (McFadden et al., 2011). Avalanche-fed glaciers, as classified in the World Glacier Inventory (WGMS, 1989), were not considered in the SA calculations because avalanches may locally significantly lower the SA.

The current extent of the accumulation areas, derived from the 2009 Landsat scene, was used for assessing the degree of imbalance of the existing glaciers. As mentioned above, the SCA and SA derived from this scene ( $\mathrm{SCA}_{2009}$ and $\left.\mathrm{SA}_{2009}\right)$ provide a rather good representation of the average extent of 
Table 2. Comparison of the mean values of the accumulation area ratio obtained from direct observations (decade 2000-2009, this work) with the value obtained from the Landsat scene of 31 August 2009, for four glaciers of the Ortles-Cevedale group. The location of the glaciers is reported in Fig. 1.

\begin{tabular}{|c|c|c|c|c|c|c|c|}
\hline \multirow[b]{2}{*}{ Glacier } & \multirow[b]{2}{*}{$\begin{array}{l}\text { Area } \\
\mathrm{km}^{2}\end{array}$} & \multicolumn{4}{|c|}{ Observed 2000-'09 } & \multirow[t]{2}{*}{$\begin{array}{l}2009 \\
\text { from } \\
\text { Landsat }\end{array}$} & \multirow[t]{2}{*}{$\begin{array}{l}\text { Difference (2009 } \\
\text { from Landsat - mean } \\
\text { 2000-'09 observed) }\end{array}$} \\
\hline & & Min & Max & $\begin{array}{c}\text { Dev. } \\
\text { St. }\end{array}$ & Mean & & \\
\hline La Mare (southern branch) & 2.1 & 0.06 & 0.76 & 0.23 & 0.34 & 0.37 & +0.03 \\
\hline Careser & 2.1 & 0.00 & 0.12 & 0.04 & 0.01 & 0.06 & +0.05 \\
\hline Fontana Bianca & 0.5 & 0.00 & 0.95 & 0.30 & 0.12 & 0.24 & +0.12 \\
\hline Rossa & 0.9 & 0.07 & 0.72 & 0.20 & 0.31 & 0.43 & +0.12 \\
\hline \multicolumn{5}{|c|}{ Area-weighted mean } & 0.19 & 0.25 & +0.06 \\
\hline
\end{tabular}

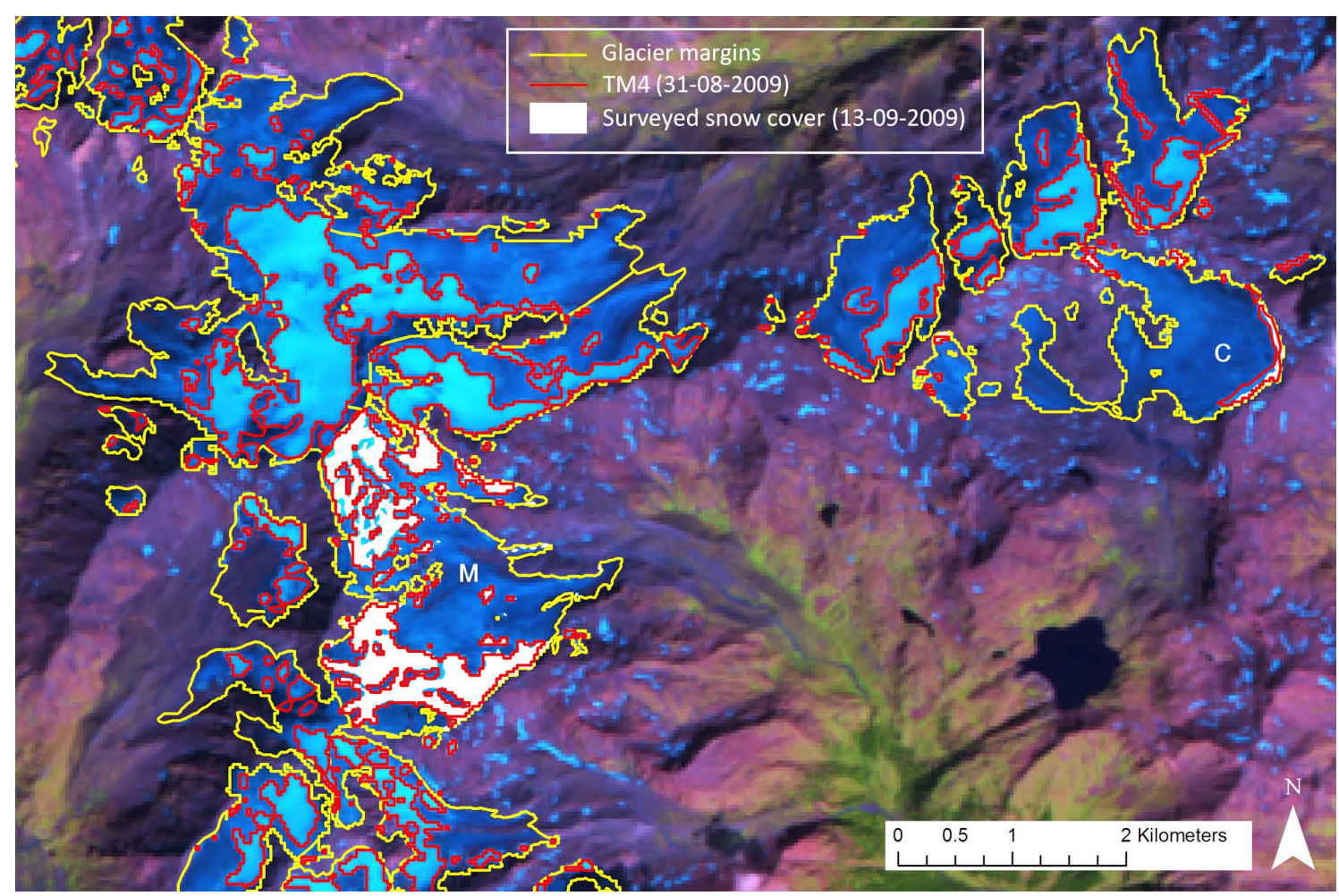

Fig. 5. Comparison of snow cover mapping from ground surveys (white areas) and from Landsat (TM4, red line) at the end of the 2009 ablation season on La Mare (M) and Careser (C) glaciers. The background image is a composite with Landsat bands TM 5, 4, and 3 as RGB.

the accumulation areas and the position of the ELA in the last decade, although their slight overestimation (Table 2), mainly due to the abundant snowfalls in winter 2009 and early date of the Landsat scene, has to be taken into account while interpreting the results of the imbalance analysis. We compared the $\mathrm{AAR}_{2009}\left(=\mathrm{SCA}_{2009} / \mathrm{A}_{2009}\right)$ and the $\mathrm{ELA}_{2009}$ (= $\mathrm{SA}_{2009}$ ) to theoretical "balanced-budget" conditions. Field evidence from long-term mass balance measurements on the Careser, Sforzellina and Fontana Bianca glaciers in the Ortles-Cevedale group indicates an average value of 0.5 for the balanced-budget $\mathrm{AAR}_{0}$ (CGI, 1978-
2011; WGMS, 2008 and 2011). This value was obtained by averaging the $\mathrm{AAR}_{0}$ of the 3 glaciers, resulting from their AAR vs. specific mass balance relationship for the whole observation period. The fractional change of the total area $\left(p_{\mathrm{s}}\right)$ necessary to reach equilibrium was calculated by comparing the $\mathrm{AAR}_{0}$ with the $\mathrm{AAR}_{2009}$, as follows (Bahr et al., 2009):

$p_{\mathrm{s}}=\alpha_{\mathrm{r}}-1$,

where $\alpha_{\mathrm{r}}$ is the ratio $\mathrm{AAR}_{2009} / \mathrm{AAR}_{0}$, which provides a measure of the extent to which each glacier is out of equilibrium (Dyurgerov et al., 2009). 


\subsection{Analysis of controls}

To highlight the controlling factors of the current glacier shrinkage, the area and elevation changes of the OrtlesCevedale glaciers were analyzed in two steps, examining (i) the entire Ortles-Cevedale glacier system and (ii) the responses of individual glaciers. For (i) we investigated the relative change in the frequency distribution of the glacierized areas and the elevation changes for classes of elevation, slope, aspect and summer clear-sky radiation. A correlation analysis was then performed considering the sample of 112 ice bodies which survived in 2009. The 10 variables used in the statistical analysis were the average values (1980s to 2000s) of mass budget, elevation, elevation range, slope, aspect, summer clear-sky radiation, AAR, fractional debris cover, area, and the "avalanche ratio" (Av), calculated as (Hughes, 2008)

$\mathrm{Av}=\frac{A_{\mathrm{av}}}{A}$,

where $A_{\mathrm{av}}$ is the avalanche contributing area, computed from a flow direction grid and a slope grid derived from the DTM, and $A$ is the total area of the glacier. The aspect was indexed before the calculations by assigning the values of 9 to south, 7 to southwest and southeast, 5 to east and west, 3 to northwest and northeast, and 1 to north.

\section{Accuracy assessment}

\subsection{Changes in glacier extent and accumulation area}

For debris-free glaciers, the typical accuracy of automated mapping from Landsat TM scenes is about $2-3 \%$, as reported by earlier assessments based on comparisons with manual delineations on higher-resolution images (e.g., Paul et al., 2002; Andreassen et al, 2008). To determine the accuracy of the outlines for the Ortles-Cevedale region, a test was carried out for a subset of 15 debris-free glaciers of different sizes, comparing the results of the automatic classification with those from manual digitizing using digital aerial orthophotos. The test confirmed this accuracy, revealing small (2-4\%) discrepancies mainly due to marginal debris-covered areas, like medial moraines and/or margins of the ablation area. Deviations one order of magnitude larger are found for debris-covered areas, which had to be manually corrected. Figure 4 shows the difference between the automated mapping with Landsat TM and the post-processed delineation of a heavily debris-covered glacier. The accuracy of this postprocessing procedure, which was mainly carried out on aerial photos, depends on (i) the characteristics of debris-covered areas (e.g., optical contrast with the surrounding terrain and the occurrence of features indicating buried ice), (ii) the characteristics of the images (shadow, contrast), and (iii) the analyst's experience in interpreting subtle details. In the absence of reference data, one possibility to estimate the precision of manually corrected glacier outlines is an independent multiple digitization of the same set of glaciers. This procedure was carried out for five debris-covered glaciers of the OrtlesCevedale, of different sizes, resulting in a standard deviation of $3 \%$, consistent with previous tests on glaciers with similar characteristics (Paul et al., 2012; Rastner et al., 2012).

The accuracy of the automatic mapping of SCA from the Landsat scenes was assessed by comparing the results of the automatic procedure with a snow cover map that was drawn from field surveys carried out on Careser and La Mare glaciers on 13 September 2009 (Fig. 5). The automatic mapping provided an $11 \%$ larger SCA than direct surveys on the ground, which can be considered as a typical deviation for the entire mountain range. A part of this discrepancy can be attributed to shortcomings in the classification method (e.g., in deep shadows), but, as observed on La Mare glacier (Sect. 3.3), the largest part has to be attributed to an actual reduction of the SCA from 31 August to 13 September, which is attributable to predominant warm weather conditions in this period. Due to the natural patchiness of snow cover, we estimate a maximum error of $\pm 50 \mathrm{~m}$ for the $\mathrm{SA}$ of individual glaciers.

\subsection{Elevation changes and mass budget}

The accuracy of the derived elevation and volume changes from the geodetic method depends mainly on the accuracy of the DTMs used. When the mean volume change rates are compared to the mean mass budget rate as measured in the field, differences due to the unknown density and basal melting or collapse occur (e.g., Huss, 2013; Zemp et al., 2013). Therefore, a direct comparison of both values is challenging (e.g., Fischer, 2011). Uncertainties related to the DTMs depend primarily on the acquisition technique of the elevation data (e.g., optical stereo, LiDAR, radar interferometry), the procedure used for their extraction from raw data, and finally their processing prior to differencing (e.g., coregistration and resampling). As mentioned in section 3.2, slope-dependent biases were not found and thus a related correction was not applied. Slope-dependent errors mainly arise when downscaling lower-resolution DTMs to a higher resolution, while in the present work the original DTMs with 2 to $10 \mathrm{~m}$ resolution were upscaled to a grid cell size of $20 \mathrm{~m}$, which is the maximum cell size of the original DTMs (Table 1).

The accuracy of the DTM differencing was assessed by applying the geostatistical procedure described in Rolstad et al. (2009). These authors mention that uncertainties depend on the standard error of individual grid point elevation differences between the two DTMs, the size of the averaging area (i.e., the size of the ice body) and the scale of the spatial autocorrelation of elevation differences. The geostatistical procedure takes into account the spatial correlation of the elevation differences, quantified over "training areas" on stable bedrock. According to this procedure, DTM differencing 
leads to a propagated uncertainty in area-averaged geodetic mass budget rates ranging from \pm 0.03 to $\pm 0.26 \mathrm{~m}$ w.e. $\mathrm{a}^{-1}$ and averaging $\pm 0.08 \mathrm{~m}$ w.e. $\mathrm{a}^{-1}$ for glaciers with an average area of $0.79 \mathrm{~km}^{2}$ in the Ortles-Cevedale group.

Density assumptions may also introduce uncertainties, particularly during periods in which changes in the density of the firn layer occur (Haug et al., 2009; Huss, 2013). Such changes likely occurred in the Ortles-Cevedale group, because the DTMs used in the calculations were acquired in the first half of the 1980s (Table 1), when glaciers still retained firn layers accumulated in the 1960s and 1970s. For this reason, a mean density of $850 \mathrm{~kg} \mathrm{~m}^{-3}$ was used. The range of uncertainty was explored by either setting a mean density of $900 \mathrm{~kg} \mathrm{~m}^{-3}$ for the entire area, or $650 \mathrm{~kg} \mathrm{~m}^{-3}$ in the $\sim 20 \%$ zone which lost the firn cover (Gardelle, 2012b; Huss, 2013), obtaining a value of $\pm 6 \%$.

\section{Results}

\subsection{Area and length changes}

The Ortles-Cevedale mountain group was subdivided into 165 glacier basins. Although small glaciers prevail in number, with only two glaciers exceeding $5 \mathrm{~km}^{2}$, much of the glacierized area is concentrated in glaciers ranging from 1 to $5 \mathrm{~km}^{2}$ (Fig. 6). We note that 32 ice bodies were already extinct in the 1980s, and another 21 glaciers completely disappeared from the 1980s to the 2000s. Over the same period, all 14 valley glaciers (i.e., glaciers flowing down a valley and having a distinct tongue; Cogley et al., 2011) have maintained their tongue, but some of them will soon get disconnected from it and transform into the mountain glacier type (i.e., glaciers in mountainous terrain, which include cirque, niche, crater or hanging glaciers, as well as ice aprons and groups of small units; Cogley et al., 2011). Table 3 shows the detected changes of key parameters for the entire glacier system (i.e., all the ice bodies are taken as one large glacier) and for the subset of the 112 ice bodies existing in 2009. Since $1987,23.4 \pm 3 \%$ of the initial glacierized area $\left(100.3 \mathrm{~km}^{2}\right)$ has been lost, and the debris-covered area has increased by $19 \%$. In 2009, 41 ice bodies were "debris-covered" (i.e., they supported a layer of debris on most or all of their ablation zone (Cogley et al., 2011)), 18 more than in 1987. Based on the source nourishment codes reported in the World Glacier Inventory (WGMS, 1989), about $90 \%$ of these 41 glaciers can be characterized as "avalanche-fed".

The average elevation of the glacierized area did not increase significantly, being $3110 \mathrm{~m}$ in the $1980 \mathrm{~s}$ and $3124 \mathrm{~m}$ in the 2000s. However, individual glacier units displayed contrasting behavior, with some small glaciers showing a significant increase in mean elevation, due to the complete melt of their lower parts or sub-units. In contrast, the largest decrease of average altitude was observed where steep glacierized slopes located at the top of accumulation areas ablated
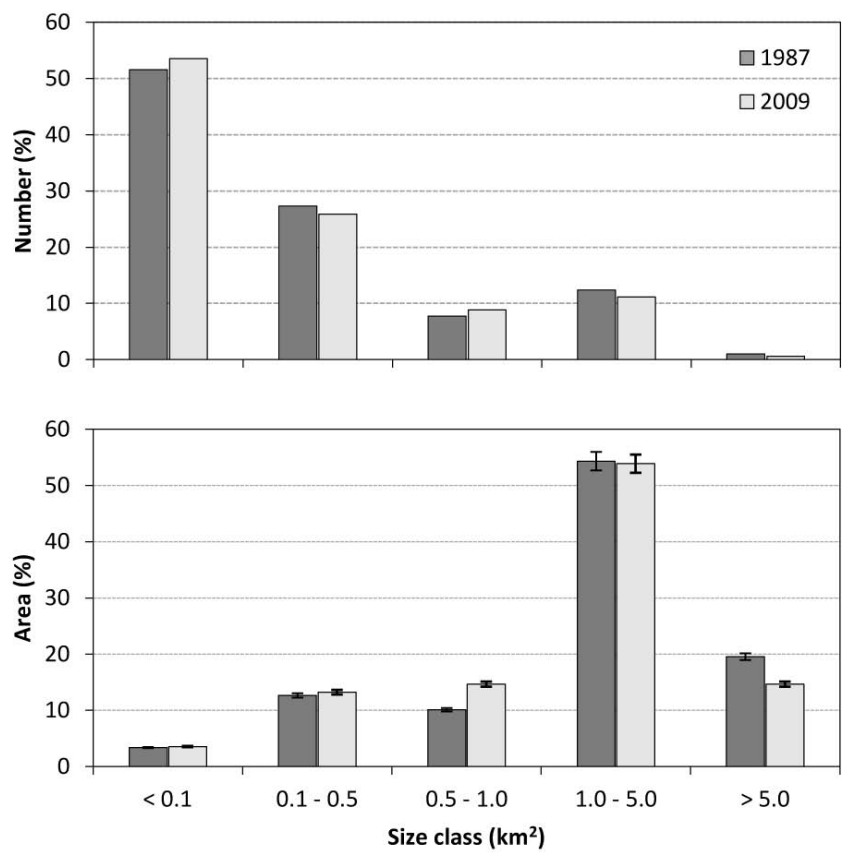

Fig. 6. Bar graphs showing percentages of glacier number and area per size classes. The area in 1987 is used as the reference for size class determination.

completely, as in the Solda glacier. The elevation range (difference between maximum and minimum elevation) exhibited a significant and widespread decrease $(-74 \mathrm{~m})$. This reduction was mainly caused by an upward shift of the minimum elevations ( $+53 \mathrm{~m}$ on average), and secondarily by the downward change of maximum elevations $(-27 \mathrm{~m}$ on average).

No notable changes were observed for the mean slope of the largest glaciers, while the smaller ice bodies displayed more variability. The mean slope increased over small residual patches in shadowed areas, with avalanched snow now accumulating at their base, and decreased in the case of vanished ice from cliffs and couloirs. A more efficient shadowing of rock walls over the lowering and retreating ice surfaces, which mainly have a northern exposure as explained below, was recognized, leading to a reduction of clear-sky radiation during summer, although this change was generally small ( $-3 \%$ on average).

The reduction of glacier areas from the 1980s to 2000s can be observed in Fig. 1, where the glacierized areas in the two epochs are overlain. The change in area since the 1980s is around $-20 \%$ for most glaciers larger than $1 \mathrm{~km}^{2}$ (Fig. 7a) with the exception of the Careser glacier, which lost $48 \%$ of its initial area. The scatter in areal reductions increases strongly for glaciers smaller than $0.3 \mathrm{~km}^{2}$, and a tendency towards a greater relative area loss with decreasing initial size is also observable. The terminus retreats were proportional to the initial length $(R=0.70)$, with (longer) valley glaciers retreating more than (shorter) mountain glaciers (Fig. 7b). 
Table 3. Change of key parameters in the Ortles-Cevedale glacier system from the 1980s to the 2000s. Error bars for average elevation change (statistics for all glaciers) have been extrapolated by the geostatistical procedure described in Sect. 4.2.

\begin{tabular}{|c|c|c|c|c|c|c|c|c|c|}
\hline & \multicolumn{3}{|c|}{ Statistics for all glaciers } & \multicolumn{6}{|c|}{ Statistics for the 112 ice bodies remaining in 2009} \\
\hline & \multirow{2}{*}{$1980 \mathrm{~s}$} & \multirow{2}{*}{$2000 \mathrm{~s}$} & \multirow{2}{*}{ Change } & \multicolumn{3}{|c|}{ Change (count \%) } & \multicolumn{3}{|c|}{ Change } \\
\hline & & & & Negative & Positive & Unchanged & Min & Max & Mean \\
\hline Area & $100.3 \mathrm{~km}^{2}$ & $76.8 \mathrm{~km}^{2}$ & $-23.5 \pm 3.0 \mathrm{~km}^{2}$ & 100 & - & - & $-48 \%$ & $-6 \%$ & $-36 \%$ \\
\hline Debris cover & $10.5 \mathrm{~km}^{2}$ & $12.5 \mathrm{~km}^{2}$ & $+2 \pm 0.3 \mathrm{~km}^{2}$ & 30 & 69 & 1 & $-67 \%$ & $+100 \%$ & $+8 \%$ \\
\hline Average elevation & $3110 \mathrm{~m}$ & $3124 \mathrm{~m}$ & $+14 \pm 0.2 \mathrm{~m}$ & 48 & 51 & 1 & $-121 \mathrm{~m}$ & $+189 \mathrm{~m}$ & $+5 \mathrm{~m}$ \\
\hline $\begin{array}{l}\text { Min-max elevation } \\
\text { range }\end{array}$ & 1795 & 1721 & $-74 \pm 5.5 \mathrm{~m}$ & 92 & 7 & 1 & $-453 \mathrm{~m}$ & $+40 \mathrm{~m}$ & $-80 \mathrm{~m}$ \\
\hline Average slope & $21.7^{\circ}$ & $21.3^{\circ}$ & $-0.4^{\circ}$ & 44 & 56 & - & $-12^{\circ}$ & $+7^{\circ}$ & $+0^{\circ}$ \\
\hline $\begin{array}{l}\text { Average clear-sky } \\
\text { radiation }\end{array}$ & $229.7 \mathrm{~W} \mathrm{~m}^{-2}$ & $228.6 \mathrm{~W} \mathrm{~m}^{-2}$ & $-1.1 \mathrm{~W} \mathrm{~m}^{-2}$ & 79 & 20 & 1 & $\begin{array}{l}-27.1 \mathrm{~W} \mathrm{~m} \mathrm{~m}^{-2} \\
(-11 \%)\end{array}$ & $\begin{array}{l}+14.3 \mathrm{~W} \mathrm{~m}^{-2} \\
(+8 \%)\end{array}$ & $\begin{array}{l}-5.9 \mathrm{~W} \mathrm{~m} \mathrm{~m}^{-2} \\
(-3 \%)\end{array}$ \\
\hline
\end{tabular}
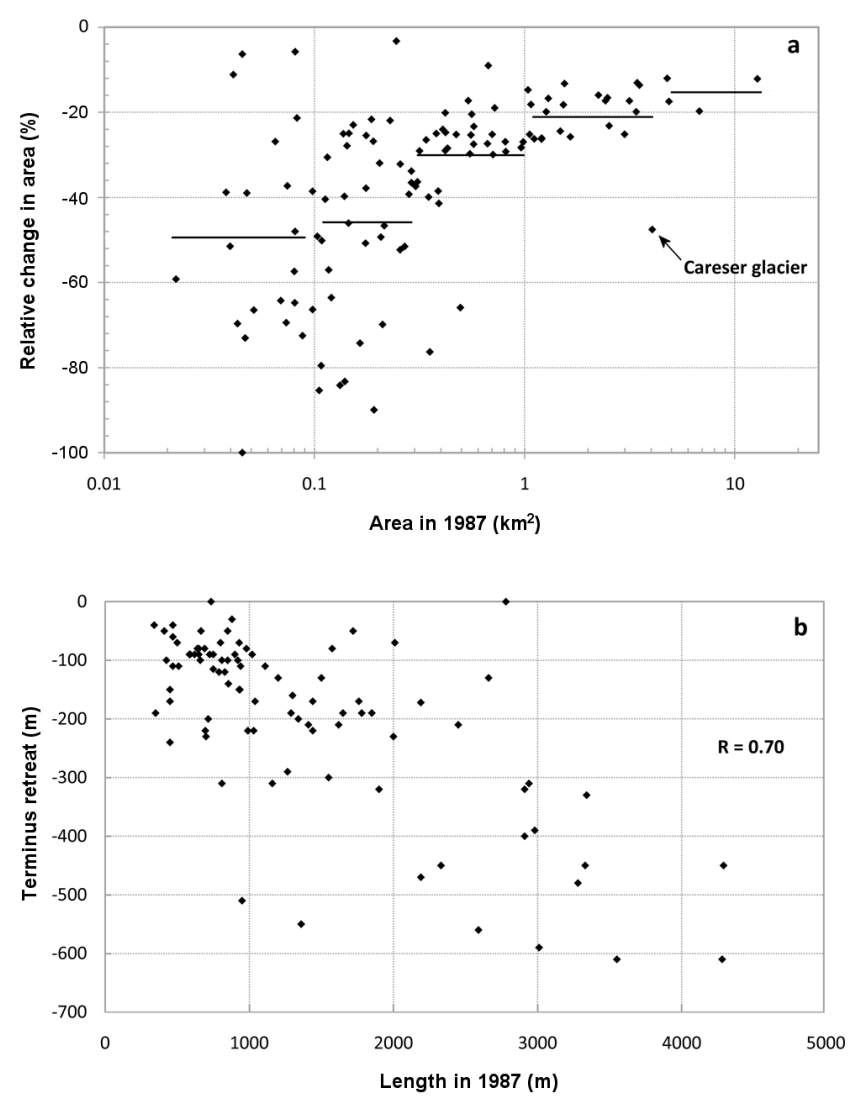

Fig. 7. (a) Relative change in area vs. initial area in 1987. Horizontal lines show mean values for distinct size classes. (b) Terminus retreat vs. initial length in 1987.

Cumulative values of retreat peak at $-610 \mathrm{~m}$ for the Forni and Forcola glaciers $\left(-27.7 \mathrm{ma}^{-1}\right)$. In some cases, single glaciers broke up into smaller ice bodies and length changes could not be measured. The most striking example is Careser glacier, where the widespread emergence of bedrock led to the fragmentation of the parent glacier (Fig. 1).

In Fig. 8 we show the change in the frequency distribution of the glacierized areas for classes of elevation, slope, aspect and summer clear-sky radiation. The area covered by glaciers decreased for all elevation classes. Figure $8 \mathrm{~b}$ suggests an increase of the relative area losses towards the steeper regions, which usually accumulate less snow and normally have a smaller ice thickness. Most of the glaciers lie on northern slopes, and the relative area change was higher over southern exposures (Fig. 8c). Nevertheless, strong area losses were also found in shaded regions, as on the formerly fully glacierized north cliffs at the top of the Solda glacier (Fig. 8d).

\subsection{Elevation changes and mass budget}

Large elevation changes have occurred in the OrtlesCevedale glacier system (Fig. 9). The total volume change is $-1.58 \mathrm{~km}^{3}$, yielding an average surface lowering rate of $0.71 \mathrm{~m} \mathrm{a}^{-1}$. Surface lowering has prevailed at all elevations, with the exception of the Mt. Ortles summit area (Alto dell'Ortles glacier), above $3800 \mathrm{~m}$ a.s.l., where negligible changes have been detected. On the other hand, maximum rates of $3.5-4 \mathrm{~m} \mathrm{a}^{-1}$ were observed in the lower parts of four valley glaciers (Forni, Basso dell'Ortles, Lunga and La Mare). Many episodes of collapsing subglacial cavities were observed in the field, which tend to accelerate the fragmentation of low-altitude, stagnant portions of glaciers. The glaciers that still retained some snow cover at the end of the ablation period had much smaller lowering rates (from 0 to $0.5 \mathrm{~m} \mathrm{a}^{-1}$ ) in their upper parts. In contrast, glaciers with small or no snow-covered areas showed high lowering rates over the entire surface, e.g., Lasa glacier (from 0.5 to $1.0 \mathrm{~m} \mathrm{a}^{-1}$ ) and, in particular, the Careser glacier (from 1.0 to $\left.2.5 \mathrm{~m} \mathrm{a}^{-1}\right)$.

Notably, the average mass budget is negative for all the ice bodies in the Ortles-Cevedale group. The arithmetic mean of the 112 individual mass budgets is $-0.69 \pm 0.12 \mathrm{~m}$ w.e. $\mathrm{a}^{-1}$, while the area-weighted mean is $-0.68 \pm 0.12 \mathrm{mw}^{\mathrm{w}}$.e. $\mathrm{a}^{-1}$. The spatial variability of the geodetic mass budget is relatively low, with a few exceptions (Fig. 10). The two extremes among all the glaciers larger than $0.3 \mathrm{~km}^{2}$ are Alto dell'Ortles $\left(-0.18 \pm 0.04 \mathrm{~m}\right.$ w.e. $\left.\mathrm{a}^{-1}\right)$ and Careser $\left(-1.43 \pm 0.09\right.$ m w.e. $\left.\mathrm{a}^{-1}\right)$. The scatterplot in Fig. 10 does not 

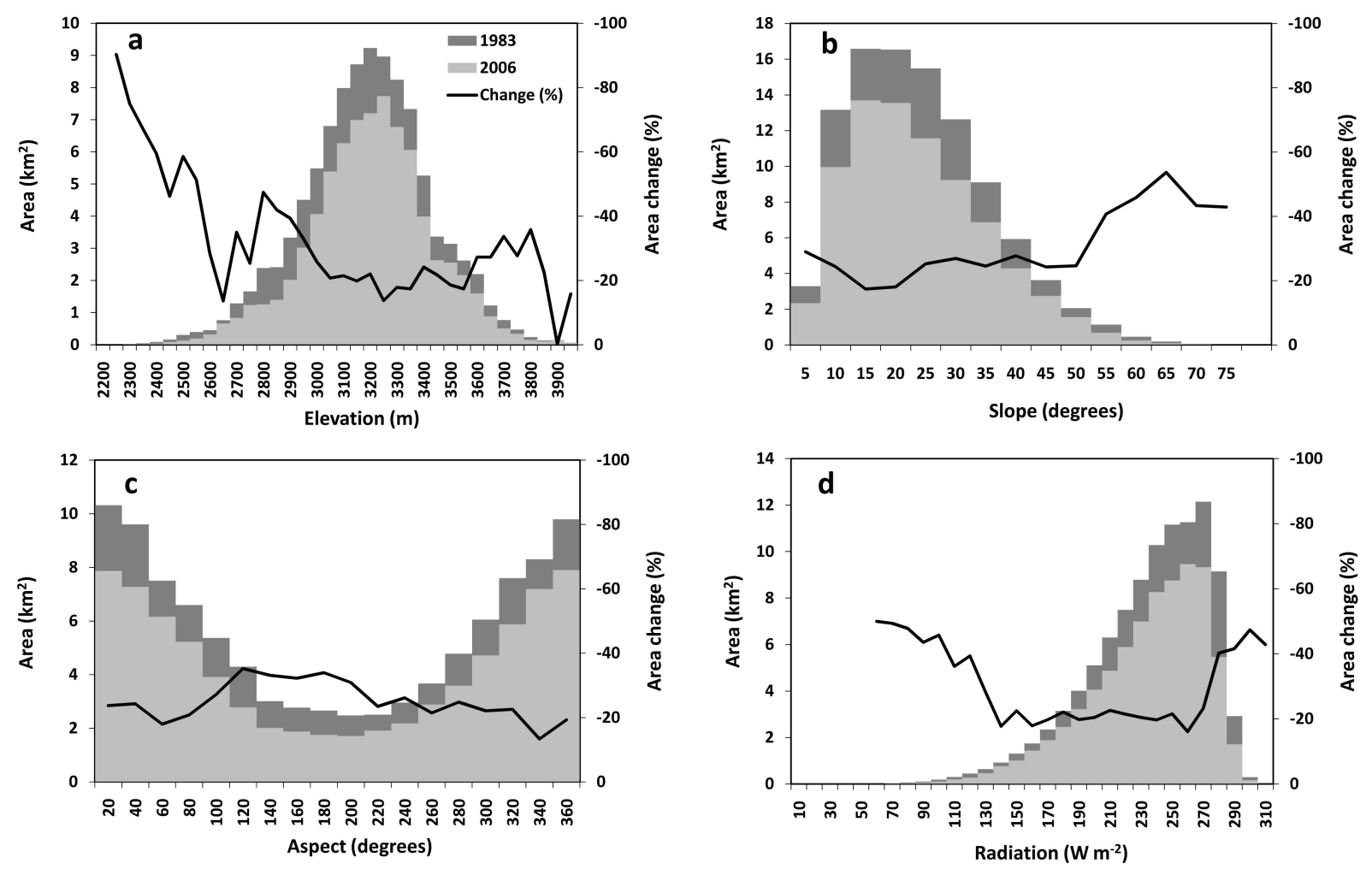

Fig. 8. Area distribution of the Ortles-Cevedale glaciers from 1987 to 2009 and percent change for classes of (a) elevation, (b) slope, (c) aspect, and (d) summer clear-sky radiation.

show the clear relationship between the mass budget and the initial glacier size that was found in the studies by Paul and Haeberli (2008) and Paul (2010), but, as was observed for the area changes, the scatter increases among ice bodies smaller than $0.3 \mathrm{~km}^{2}$.

The vertical profile of the elevation changes over the entire glacierized area remaining in the 2000s (Fig. 11a) shows maximum lowering rates of $-1.3 \mathrm{ma}^{-1}$ at $\sim 2700 \mathrm{~m}$ a.s.l. Interestingly, below this altitude, decreasing lowering rates were found, with a minimum of $-0.2 \mathrm{~m} \mathrm{a}^{-1}$ at $2300 \mathrm{~m}$ a.s.l., likely as a result of the large share of debris-covered glaciers. Flat areas lowered more rapidly than steeper areas (Fig. 11b), and stronger elevation losses were detected across slopes with southern exposure (Fig. 11c) or higher radiation inputs (Fig. 11d) with the exception of the poorly represented classes of summer clear-sky radiation.

\subsection{Extent of snow-covered area and current degree of imbalance}

The snow-covered area (SCA) was $7 \mathrm{~km}^{2}(23.4 \%)$ smaller in 2009 than in 1987 (Fig. 12). The average snowline altitude $\left(=\left(\mathrm{SA}_{1987}+\mathrm{SA}_{2009}\right) / 2\right)$ ranged from $3094 \mathrm{~m}$ on the northern slopes to $3335 \mathrm{~m}$ on the southern slopes. The snowline altitude was $45 \mathrm{~m}$ higher for areas exposed to the east (3223 m) than for those to the west $(3178 \mathrm{~m})$. The average SA of the glacier system, normalized as a function of the exposure, was $3215 \mathrm{~m}$ in 1987 and $3223 \mathrm{~m}$ in 2009, showing negligible differences between these $2 \mathrm{yr}$.

The index $\alpha_{\mathrm{r}}\left(\mathrm{AAR}_{2009} / \mathrm{AAR}_{0}\right.$ in Eq. 3) is at present lower than 1 in most cases, indicating that nearly all glaciers have to reduce their total area (by $40 \%$ on average) to reach a balanced budget under the current climatic conditions. For 17 out of 112 cases, the resulting equilibrium areas are less than $0.01 \mathrm{~km}^{2}$, indicating impending extinction. According to Eq. (3), among the glaciers larger than $1 \mathrm{~km}^{2}$, further remarkable area losses are expected for the Careser $(-87 \%)$ and Lasa ( $-66 \%$ ) glaciers. Conditions closer to equilibrium, with an expected area loss of $6 \%$, were found for the highestaltitude glacier (Alto dell'Ortles, which has a mean elevation of $3425 \mathrm{~m}$ ). Large area losses are expected in general for valley glaciers ( $-34 \%$ on average). Among them, the Cevedale and Dosegù glaciers still have a relatively large accumulation area $\left(\mathrm{AAR}_{2009}=0.45\right)$ and are closer to a balanced budget.

\subsection{Analysis of controls}

The results of the correlation analysis among average geodetic mass budgets and nine other variables are shown in Table 4 . The subset of 51 glaciers larger than $0.3 \mathrm{~km}^{2}$ showed highly significant $(0.01$ level $)$ correlations between mass budget and slope, AAR and elevation range. The correlations 
Table 4. Correlation matrix for ten variables. Correlations significant at the $0.01,0.05$ and 0.10 levels are marked in bold type, bold-italic and italic, respectively. Glaciers larger than $0.3 \mathrm{~km}^{2}$ are in the lower left $(n=51)$, glaciers smaller than $0.3 \mathrm{~km}^{2}$ are in the upper right $(n=61)$.

\begin{tabular}{lrrrrrrrrrr}
\hline & $\begin{array}{r}\text { Mass } \\
\text { budget }\end{array}$ & Elevation & Slope & Aspect & $\begin{array}{r}\text { Clear-sky } \\
\text { radiation }\end{array}$ & AAR & $\begin{array}{r}\text { Debris } \\
\text { cover }\end{array}$ & $\begin{array}{r}\text { Elevation } \\
\text { range }\end{array}$ & $\begin{array}{r}\text { Area } \\
\text { Avalanche } \\
\text { ratio }\end{array}$ \\
\hline Mass budget & 1.00 & 0.06 & $\mathbf{0 . 4 0}$ & 0.07 & -0.12 & 0.23 & $\mathbf{0 . 3 3}$ & 0.16 & -0.19 & $\mathbf{0 . 4 0}$ \\
Elevation & 0.23 & 1.00 & -0.18 & $\mathbf{0 . 6 5}$ & $\mathbf{0 . 7 3}$ & $\mathbf{0 . 4 8}$ & $\mathbf{- 0 . 4 9}$ & 0.05 & 0.08 & $-\mathbf{0 . 2 3}$ \\
Slope & $\mathbf{0 . 4 8}$ & -0.14 & 1.00 & $-\mathbf{0 . 3 5}$ & $-\mathbf{0 . 6 8}$ & -0.13 & $\mathbf{0 . 4 4}$ & $\mathbf{0 . 4 7}$ & -0.15 & $\mathbf{0 . 3 2}$ \\
Aspect & -0.06 & $\mathbf{0 . 4 7}$ & $-\mathbf{0 . 2 7}$ & 1.00 & $\mathbf{0 . 8 3}$ & $\mathbf{0 . 2 6}$ & -0.16 & -0.17 & -0.12 & 0.16 \\
Clear-sky radiation & -0.14 & $\mathbf{0 . 6 9}$ & $-\mathbf{0 . 6 6}$ & $\mathbf{0 . 7 5}$ & 1.00 & $\mathbf{0 . 3 2}$ & $-\mathbf{0 . 4 0}$ & $-\mathbf{0 . 3 2}$ & 0.01 & -0.08 \\
AAR & $\mathbf{0 . 4 7}$ & $\mathbf{0 . 5 4}$ & 0.13 & -0.02 & 0.13 & 1.00 & $-\mathbf{0 . 5 2}$ & 0.23 & 0.14 & 0.02 \\
Debris cover & 0.17 & $-\mathbf{0 . 5 9}$ & $\mathbf{0 . 4 7}$ & -0.01 & $-\mathbf{0 . 4 8}$ & $-\mathbf{0 . 3 9}$ & 1.00 & -0.16 & $-\mathbf{0 . 4 2}$ & $\mathbf{0 . 5 7}$ \\
Elevation range & $\mathbf{0 . 4 8}$ & -0.02 & $\mathbf{0 . 3 2}$ & -0.12 & $-\mathbf{0 . 2 7}$ & $\mathbf{0 . 4 0}$ & 0.08 & 1.00 & $\mathbf{0 . 5 7}$ & 0.04 \\
Area & 0.01 & 0.11 & $-\mathbf{0 . 2 8}$ & -0.05 & 0.15 & $\mathbf{0 . 3 4}$ & $-\mathbf{0 . 3 0}$ & $\mathbf{0 . 4 9}$ & 1.00 & $-\mathbf{0 . 3 4}$ \\
Avalanche ratio & $\mathbf{0 . 2 8}$ & $-\mathbf{0 . 3 3}$ & $\mathbf{0 . 5 0}$ & 0.22 & $-\mathbf{0 . 2 8}$ & -0.25 & $\mathbf{0 . 8 0}$ & 0.15 & $-\mathbf{0 . 3 1}$ & 1.00 \\
\hline
\end{tabular}

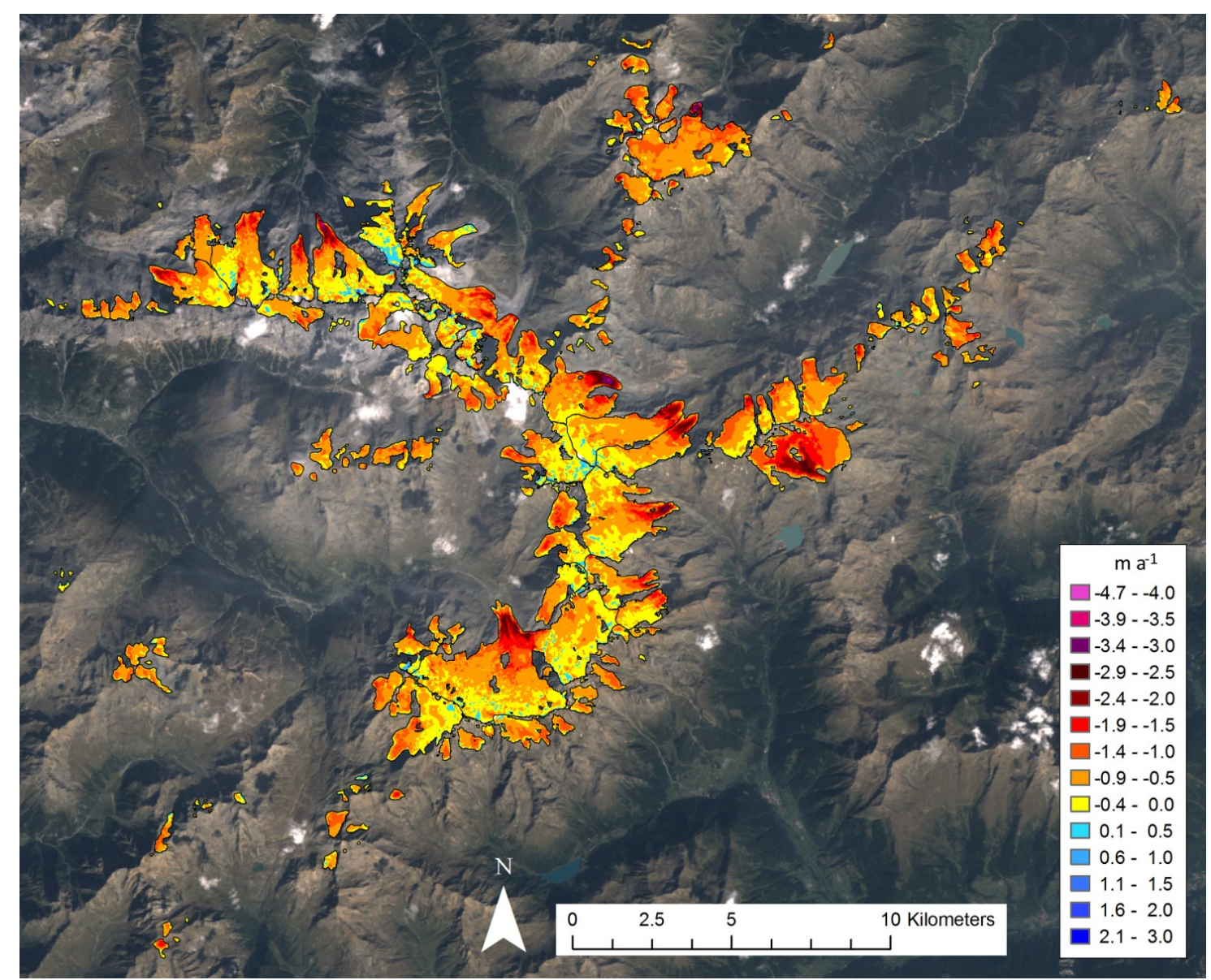

Fig. 9. Mean annual elevation change rates of the Ortles-Cevedale glaciers from the period 1981-1984 to 2005-2007, on a cell-by-cell basis.

with elevation and avalanche ratio are less significant $(0.10$ and 0.05 levels, respectively), while there is no significant correlation between mass budget and aspect, clear-sky radiation, debris cover or area. The glaciers with higher elevation ranges and higher mean elevations also have higher AARs. The AAR is in turn highly correlated with area and (inversely) with debris cover. The glaciers with higher radiation inputs and less topographic shading are located at higher altitudes, and vice versa. By contrast, increasing debris cover enables the existence of ice masses at lower elevations and is highly correlated with avalanche activity, as expressed by the avalanche ratio (Eq. 4). 


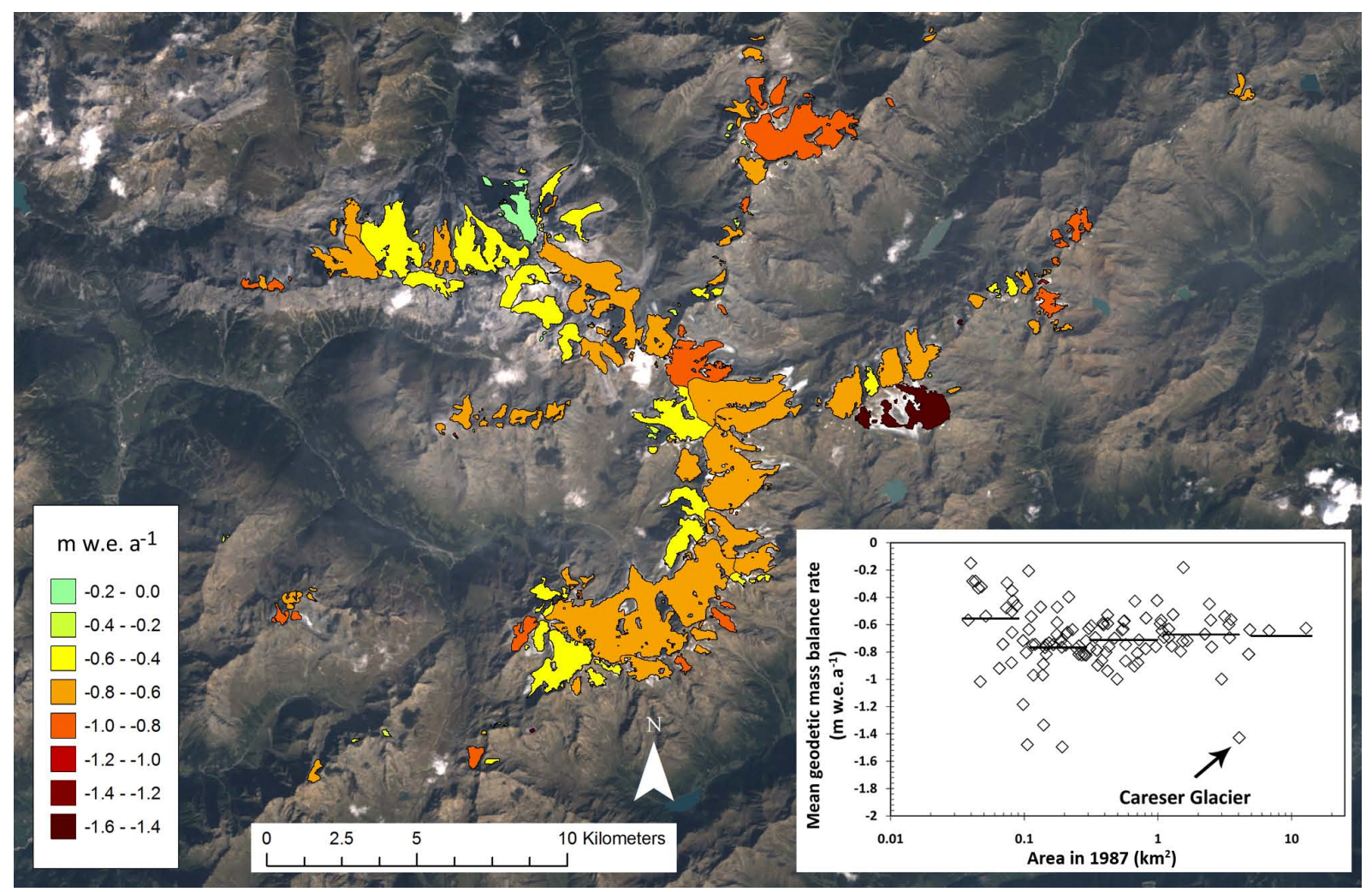

Fig. 10. Glacier specific mean geodetic mass balance rates calculated from the values shown in Fig. 9. The scatterplot shows the values plotted vs. initial area in 1987.

The group of 61 glaciers smaller than $0.3 \mathrm{~km}^{2}$ produced quite different results. Among the analyzed variables, slope, debris cover and avalanche ratio displayed the highest correlation with mass budget. The absence of a significant correlation with elevation and the lower significance of the correlation with AAR, in contrast to the results for larger glaciers, are remarkable but somewhat expected for these small ice bodies. Glaciers with higher altitudes have less debris cover and are less shielded from solar radiation. Slope is inversely correlated with aspect and clear-sky radiation and directly correlated with debris cover and elevation range. As was observed for the larger glaciers, the ice bodies with higher debris cover are also mainly avalanche-fed.

\section{Discussion}

\subsection{Glacier changes and controls}

The area loss rate of the Ortles-Cevedale glacier system, with reference to the initial area in 1987 , was $-1.1 \pm 0.1 \% \mathrm{a}^{-1}$, which is slightly lower than the recent Alpine-wide estimate of $-1.4 \% \mathrm{a}^{-1}$ between 1984 and 2003 found by Paul et al. (2011), when referring to the initial area of about $2900 \mathrm{~km}^{2}$. Similarly, Paul et al. (2004) found an area loss rate of $-1.3 \% \mathrm{a}^{-1}$ for the Swiss glaciers from 1985 to
1999, while Lambrecht and Kuhn (2007) calculated a rate of $-0.6 \% \mathrm{a}^{-1}$ for the Austrian glaciers during the period of 1969-1998. However, the latter includes the expansion period of 1973-1985 and must thus be smaller. If the total area change in this period is assumed to be close to zero, the rate over the $1985-1998$ period is $-1.2 \% \mathrm{a}^{-1}$. Abermann et al. (2009) calculated an increase in area loss rates from $-0.4 \% \mathrm{a}^{-1}$ in the period of $1969-1997$ to $-0.9 \% \mathrm{a}^{-1}$ in the period of 1997-2006 in the Austrian Ötztal Alps. Concerning the Italian Alps, Knoll and Kerschner (2009) quantified a reduction rate of $-1.4 \% \mathrm{a}^{-1}$ for the South Tyrol glaciers from 1983 to 2006, highlighting a significantly lower reduction rate $\left(-1.1 \% \mathrm{a}^{-1}\right)$ for the portion of the Ortles-Cevedale glaciers that lies in the province of Bolzano, which is consistent with our results in this area $\left(-1.0 \% \mathrm{a}^{-1}\right)$. Larger reduction rates $\left(-1.8 \% \mathrm{a}^{-1}\right)$ were found from 1981 to 2003 for the glacier system of the Dosdè-Piazzi group, about $20 \mathrm{~km}$ west of the Ortles-Cevedale (Diolaiuti et al., 2011). Citterio et al. (2007) calculated an area reduction of $-1.5 \% \mathrm{a}^{-1}$ for 249 glaciers in the Lombardia region from 1992 to 1999 . Finally, Maragno et al. (2009) estimated $-0.9 \% \mathrm{a}^{-1}$ for the Adamello group, $35 \mathrm{~km}$ southwest of the Ortles-Cevedale, during the period of 1983-2003.

The spatial pattern of the area changes shows significant area losses even at high altitudes (Fig. 8a), causing a 

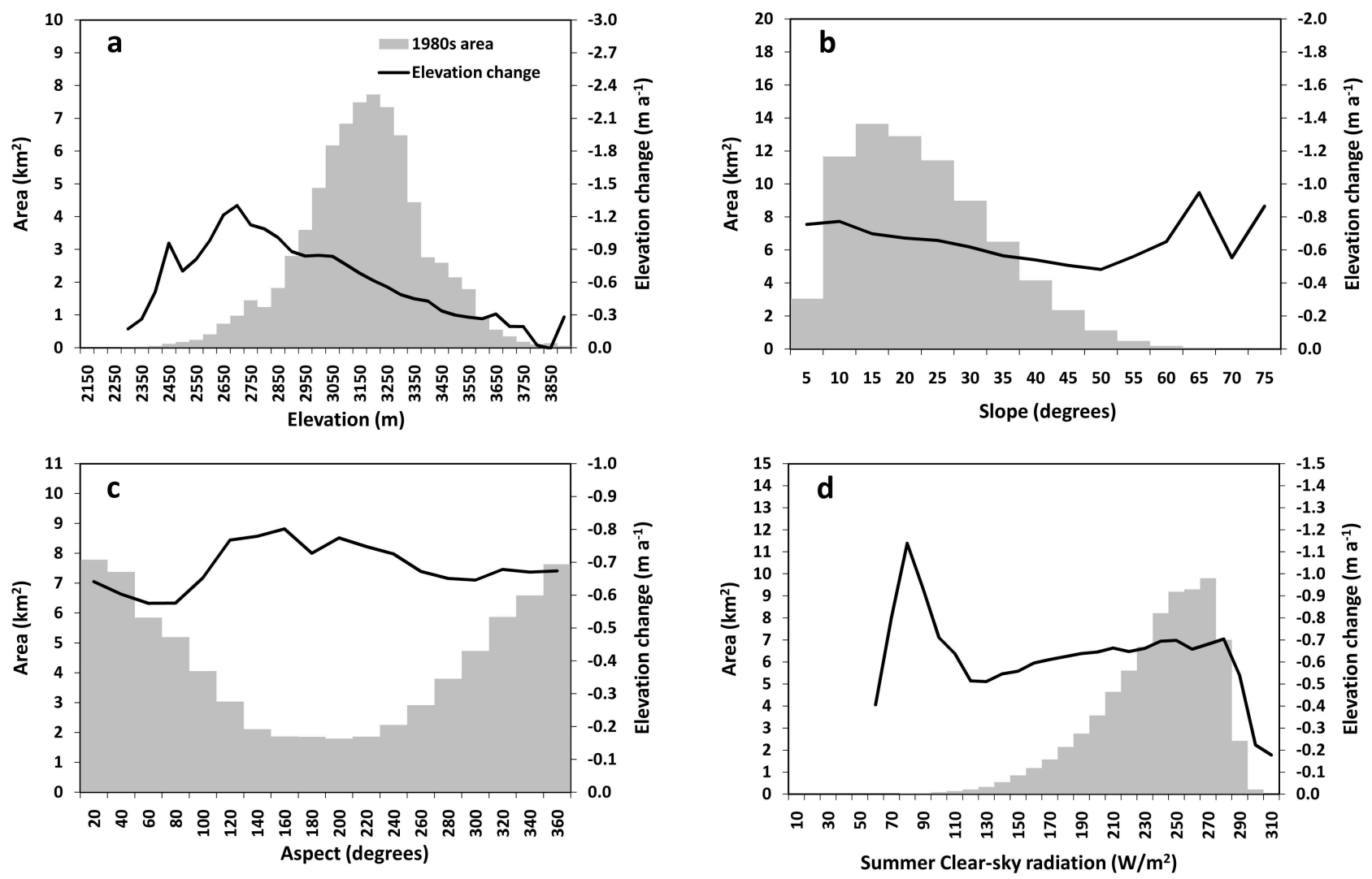

Fig. 11. Elevation changes of the Ortles-Cevedale glacier system from the 1980s to the 2000s, for classes of (a) elevation, (b) slope, (c) aspect and (d) summer clear-sky radiation. Calculations were performed over the 2000s glacierized area. The area distribution in the 1980s is shown to give a background for the reported elevation changes.

substantial lack of adjustment of the area-averaged elevation of the glacier system $(+14 \mathrm{~m})$. This can be explained by considering the physical characteristics of the high-altitude glacierized areas of the Ortles-Cevedale group, which are typically steep and convex and receive relatively little accumulation during winter (see for example the Glacierreports of Ufficio Idrografico - Autonomous Province of Bolzano: http://www.provinz.bz.it/wetter/glacierreport.asp). These high-elevation areas should benefit from the accumulation of wet snow during the warmer part of the year. However, due to less abundant summer snowfall (Fig. 13c), they are often exposed to net ablation during the summer. This retreat of the head of the glaciers indicates disequilibrium conditions, because this occurs due to thinning of the upper accumulation zone (Pelto, 2010).

Factors causing negative feedbacks on glacier wastage were detected in this study, such as an increase in debris cover and decrease of clear-sky radiation during summer, due to increased topographic shading for some glaciers. However, overall these feedbacks were not effective so far in offsetting the effects of increasing temperatures (Fig. 13a).

The average geodetic mass budget of the glaciers is indeed highly negative $\left(-0.7 \mathrm{~m}\right.$ w.e. $\left.\mathrm{a}^{-1}\right)$ and close to the average of nine glaciers with long-term direct measurements in the European Alps $\left(-0.8 \mathrm{~m}\right.$ w.e. $\left.\mathrm{a}^{-1}\right)$ during the same period (Zemp et al., 2005; WGMS, 2008, 2009 and 2011). These two estimates come from different methods, which can give quite different results depending on factors such as the density assumptions, basal or internal melt and errors in measuring and/or extrapolating direct measurements (Krimmel, 1999; Fischer, 2011). Nevertheless, the two methods provided very similar results on the Careser glacier from 1983 to 2006

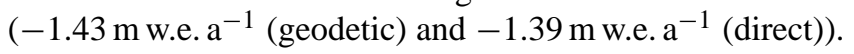
Similarly, good results were obtained also for the other two glaciers with long-term direct measurements, although these lack some years on record (Sforzellina: $-0.86 \mathrm{~m}$ w.e. $\mathrm{a}^{-1}$ (geodetic) and $-1.08 \mathrm{~m}$ w.e. $\mathrm{a}^{-1}$ (direct), the latter missing 6 years out of 26 ; Fontana Bianca: $-0.90 \mathrm{~m}$ w.e. $\mathrm{a}^{-1}$ (geodetic) and $-0.86 \mathrm{~m}$ w.e. $\mathrm{a}^{-1}$ (direct), the latter missing $3 \mathrm{yr}$ out of 21).

The elevation changes vs. altitude plot (Fig. 11a) displays a trend that is different from the findings of Lambrecht and Kuhn (2007). In the latter study the trend resembled the vertical balance profile of a "clean glacier" (i.e., a glacier without debris cover), with increasing elevation loss rates towards lower elevations. In our study, the trend more closely recalls 


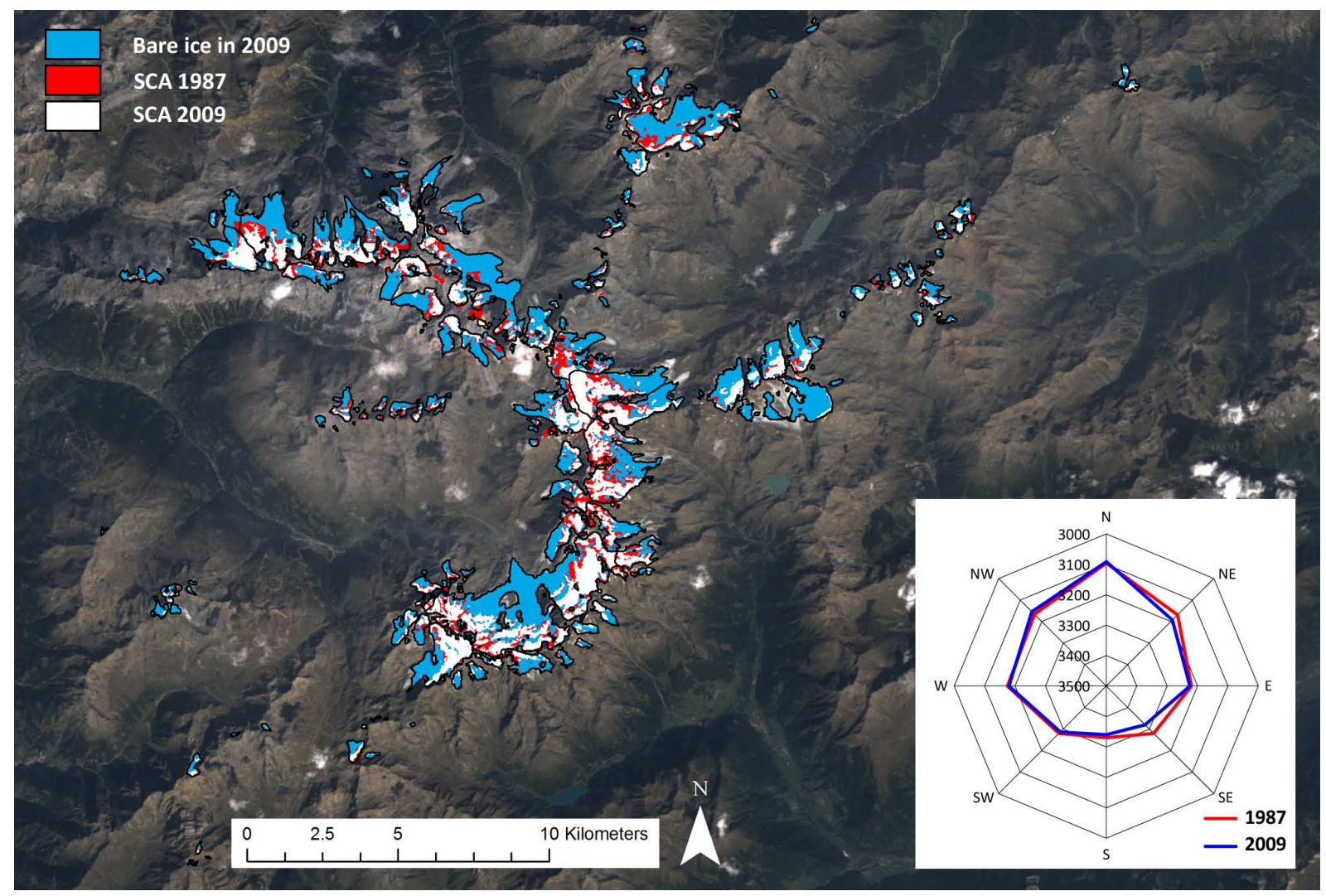

Fig. 12. Snow-covered area in the late summer of 1987 (red and white) and 2009 (white only). Light blue represents bare ice in 2009 ; white + red + blue $=$ glacier area in 2009 . The radar chart shows the snow line altitude versus main aspect direction in both years.

the vertical mass balance profile of debris-covered glaciers (e.g., Benn and Lehmkuhl, 2000), marked by decreasing elevation loss rates below $2700 \mathrm{~m}$. Actually, the only areas that extend below this altitude in the Ortles-Cevedale are glacier tongues with thick debris cover, which insulate them reducing ablation, that are mainly clustered in the region of Mt. Ortles (Solda, Marlet and Finimondo glaciers). Of course, the observed vertical profile of elevation changes also includes dynamic adjustments. However, no experimental data were available in the Ortles-Cevedale group for a quantitative assessment of this process.

The positive correlations of the average mass budgets of the 51 glaciers larger than $0.3 \mathrm{~km}^{2}$ with their elevation range, AAR, mean elevation and slope confirm the role of hypsometry in controlling the sensitivity of glaciers and their response to climate fluctuations (Furbish and Andrews, 1984; Benn and Evans, 2010). The negative correlations reported by other authors (e.g., Chueca et al., 2007; Paul and Haeberli, 2008) between mass budget and area and between mass budget and potential shortwave radiation in summer were not found in the Ortles-Cevedale, most likely due to the peculiar characteristics of the glaciers in this mountain group and/or the much smaller range of glacier sizes. Indeed, in the OrtlesCevedale, the glacier area is highly correlated with the ele- vation range (i.e., larger glaciers extend farther in altitude and still retain accumulation areas), and the valley tongues of larger glaciers, which should undergo larger mass losses, are already reduced (e.g., the Forni glacier) or debris-covered (e.g., the Solda glacier). The lack of a correlation between the mass budget and potential shortwave radiation might be attributed to the high mean elevation of the glaciers that receive higher shortwave radiation inputs (elevation is highly correlated with potential shortwave radiation).

A clear difference exists between glaciers that maintain accumulation areas and show dynamic retreat and an "equilibrium response", and glaciers with low elevation ranges, almost entirely below the ELA and exhibiting down-wasting and a "disequilibrium response" (Pelto, 2006 and 2010). The Careser glacier, whose area and mass loss rates were much higher than average (Figs. 7a and 10), exemplifes the behavior of the latter group, composed of glaciers without a consistent accumulation zone, which can thus not survive under the present climate conditions. This comparatively flat glacier lies below the ELA and has lacked an accumulation area in most of the past $30 \mathrm{yr}$. Careser glacier thus behaved like a stagnant block of ice that is melting down. The lowering of the albedo and increased thermal emission from the growing patches of ice-free terrain likely act as positive feedbacks, 

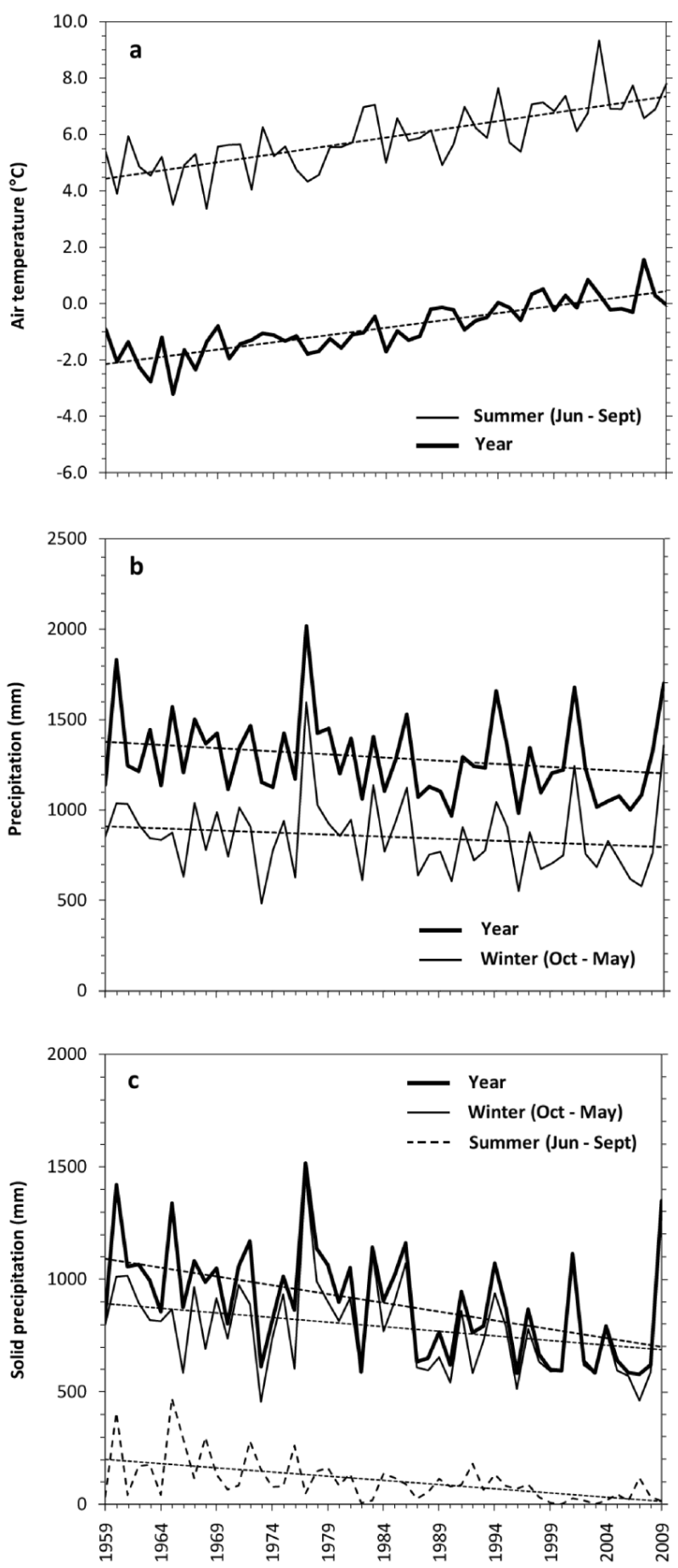

Fig. 13. Time series of meteorological observations from 1959 to 2009 at the Careser dam weather station (2605 m a.s.1.): (a) air temperature; (b) total precipitation; (c) solid precipitation.

which accelerate the down-wasting and fragmentation of this glacier (e.g., Oerlemans et al., 2009). The continuation of its long-term mass balance series is at risk, and care should be taken in interpreting and extrapolating mass balance results of this glacier.
Glaciers smaller than $0.3 \mathrm{~km}^{2}$ displayed greater variability in the individual responses (Figs. 7a and 10) and less obvious control of their behavior. Notably, AAR and elevation show little or no correlation with the mass budget, likely because these small ice bodies are more influenced by local topo-climatic conditions and are somewhat decoupled from regional-scale climatic trends (Kuhn, 1995; Hughes, 2008; DeBeer and Sharp, 2009; Carturan et al., 2013). Most of them are remnants of formerly much larger glaciers that are now protected from ablation by topographic shading and/or debris cover, and take advantage of additional snow accumulation by avalanches. Some of them, namely those located in steep terrain at high altitudes, show little change over the analyzed period.

\subsection{Extent of accumulation area and current degree of imbalance}

The comparison of the current values of AAR $\left(\mathrm{AAR}_{2009}\right.$, which fairly reflects the average conditions in the previous decade) and the balanced-budget $\mathrm{AAR}_{0}$ ( 0.5 for the OrtlesCevedale, based on available mass balance series) demonstrates that the glaciers of this mountain group will continue to shrink and retreat, even without additional atmospheric warming. However, taking into account the small overestimation of the mean AAR in the last $10 \mathrm{yr}$, due to the use of the $\mathrm{SCA}_{2009}$ (Table 2), the expected average reduction in area of $40 \%$ has to be interpreted as a lower bound value. Considering this issue and the difficulties concerning the calculation of the $\mathrm{AAR}_{0}$ (i.e., the small sample of glaciers with sufficiently long mass balance series and the high variability of $\mathrm{AAR}_{0}$ for single glaciers), the expected areal reduction rises to $\sim 50 \%$.

Interestingly, some glaciers like Finimondo and Marlet show an apparent discrepancy between their observed slightly negative mass budget and the high degree of imbalance which they should experience, given their current low AAR. This finding can be explained by considering that in high-mountain environments the spatial distribution of mass balance and, as a consequence, the value of the $\mathrm{AAR}_{0}$ can be largely affected by avalanching, debris cover, and topographic effects (Benn and Lehmkuhl, 2000; Benn and Evans, 2010). In particular, glaciers with thick and extensive debris cover, such as Finimondo and Marlet, tend to have much lower values of $\mathrm{AAR}_{0}$, because their surface ablation rates are lower when compared to "clean" glaciers, largely due to the insulating effect from debris (Nicholson and Benn, 2006).

The balanced-budget ELA ( $\left.\mathrm{ELA}_{0}\right)$, corresponding to the balanced-budget $\mathrm{AAR}_{0}(0.5)$, was calculated from the hypsometry of all glaciers of the Ortles-Cevedale group and was compared to current observations of the SA. The $\mathrm{SA}_{2009}$ $(3223 \mathrm{~m})$ is $92 \mathrm{~m}$ higher than the current $\operatorname{ELA}_{0}(3131 \mathrm{~m})$ and $156 \mathrm{~m}$ higher than the $\mathrm{ELA}_{0}$ in the $1980 \mathrm{~s}$ (3067 m). However, since most glaciers were expanding during the first half of the 1980s, a somewhat lower ELA should have been present in 
the 10-20 preceding years (1960s-1970s). Based on the mass balance series of the Careser glacier, we can estimate a mean ELA of $2984 \mathrm{~m}$ in the period from 1967 to 1980, which is $239 \mathrm{~m}$ lower than the $\mathrm{SA}_{2009}$ and $83 \mathrm{~m}$ lower than the $\mathrm{ELA}_{0}$ in the 1980s.

The recent behavior of glaciers in the European Alps was characterized by two contrasting periods: the 1960s to the 1970s, when a general expansion was observed, and the 1980s to the 2000s, when a strong recession occurred (Patzelt, 1985; Citterio et al., 2007; Zemp et al., 2008). These two periods can be clearly linked to meteorological data series recorded at $2605 \mathrm{~m}$ by the Careser dam weather station (Fig. 13), which shows strong positive trends for both annual $\left(+0.5^{\circ} \mathrm{C}\right.$ per decade $)$ and summer $\left(+0.6^{\circ} \mathrm{C}\right.$ per decade $)$ temperatures. The mean annual temperature increased by $1.6{ }^{\circ} \mathrm{C}$ from the first to the second period, resulting in an ELA change of $+147 \mathrm{~m}^{\circ} \mathrm{C}^{-1}$. This value lies in the range of $100-170 \mathrm{~m}^{\circ} \mathrm{C}^{-1}$ reported for other glacierized regions in the literature (e.g., Brock et al., 2000; Klok and Oerlemans, 2002; Gerbaux et al., 2005; Paul et al., 2007b; Zemp et al., 2007). Although the temperature increase is the dominant characteristic of the observed climate change, the precipitation trends were also unfavorable for the Ortles-Cevedale glaciers, showing a decrease of $2.5 \%$ per decade in both the annual and winter values. Remarkably, solid precipitation exhibited larger trends $(-7.2 \%,-4.5 \%$ and $-16.2 \%$ per decade for the annual, winter and summer values, respectively).

\section{Conclusions}

We have analyzed the changes in area, length and volume of the glaciers in the Ortles-Cevedale group from the 1980s to the 2000s, using two Landsat scenes (from 1987 and 2009) and calculating the difference between two digital terrain models. We investigated the role of several topographic parameters in controlling the spatial variability of the glacier shrinkage and the degree of imbalance of the glaciers by comparing the AAR derived from their end-of-summer snow-covered area (SCA) with the balanced-budget $\mathrm{AAR}_{0}$.

During the investigated period, the Ortles-Cevedale glaciers lost $23.4 \pm 3 \%$ of their area, displaying no significant adjustments of their mean altitude. In total 21 ice bodies became extinct. The average area loss rate $(-1.1 \pm 0.1$ $\left.\% \mathrm{a}^{-1}\right)$ and mass loss rate $\left(-0.69 \pm 0.12 \mathrm{~m}\right.$ w.e. $\left.\mathrm{a}^{-1}\right)$ were well within the range of previously assessed values in other regions of the European Alps. Consistently with previous studies, the fractional area change of the Ortles-Cevedale glaciers was inversely related to the initial glacier size, and the terminus retreat was proportional to the initial length. In contrast, the individual mass loss rates were not related to the initial glacier size and clear-sky solar radiation, as found in other studies.
The different responses of the Ortles-Cevedale glaciers to climate change are mainly controlled by their hypsometry (slope, elevation and elevation range). Glaciers with large vertical extents still retain accumulation areas and show active retreat, while flat glaciers below the current equilibrium line altitude (ELA) experienced strong mass losses over their entire surface, likely magnified by positive feedbacks such as albedo lowering and thermal emission from the increasingly large rock outcrops. The Careser glacier is the most striking example of this behavior, showing mass loss rates that are nearly double the average. Consequently, this glacier and its 45-year-long mass balance series would end rather soon. Very small glaciers with areas $\leq 0.3 \mathrm{~km}^{2}$ displayed much greater variability in their individual responses, because they are increasingly influenced by local topo-climatic conditions and are somewhat decoupled from regional climate. Among them, those that are avalanche-fed and/or debris-covered experienced smaller mass losses.

To reach equilibrium under the climatic conditions which characterized the last decade, the Ortles-Cevedale glacier system would need to lose $\sim 50 \%$ of its present area. The snowline altitude (SA) is now $\sim 100 \mathrm{~m}$ higher than it should be for balanced-budget conditions, and it is $\sim 250 \mathrm{~m}$ higher than during the short period of expansion that occurred from the 1960 s to the beginning of 1980 s. Hence, glaciers will continue to shrink even if temperature does not further increase. On the other hand, the special characteristics of individual glaciers in the steep areas of the Ortles-Cevedale group (e.g., influenced by avalanching, topographic shading and heavily debris-covered) will favor their persistence.

\section{Supplementary material related to this article is available online at: http://www.the-cryosphere.net/7/ 1339/2013/tc-7-1339-2013-supplement.zip.}

Acknowledgements. This is contribution no. 4 to the Ortles Project (http://www.ortles.org). The study was funded by the Italian MIUR Project (PRIN 2010-11): "Response of morphoclimatic system dynamics to global changes and related geomorphological hazards" (local and national coordinators G. Dalla Fontana and C. Baroni). Analysis resources were provided by the Interdepartmental Research Center for Cartography, Photogrammetry, Remote Sensing and GIS (CIRGEO), at the University of Padova. Paolo Gabrielli acknowledges financial support from NSF award \# 1060115. This is also Byrd Polar Research Center contribution no. 1434. We thank Fondazione Caritro, which supported the visiting scholarship of R. Filippi at the Byrd Polar Research Center and EURAC, and M. Lanzinger (Museo delle Scienze di Trento) for facilitating this visiting scholarship. Topographic data were provided by the Regione Lombardia and by the Autonomous Provinces of Trento and Bolzano. Meteorological data for the Careser dam were provided by Meteotrentino. The field work for mass balance measurements on Fontana Bianca glacier was 
carried out by the Ufficio Idrografico of the Autonomous Province of Bolzano. The field work for mass balance measurements on Careser glacier was carried out under the auspices of the Comitato Glaciologico Italiano, in cooperation with Meteotrentino, Museo delle Scienze di Trento, Comitato Glaciologico Trentino - SAT, Dipartimento di Ingegneria dell'Università di Trento. C. Smiraglia kindly provided unpublished mass balance data for the Sforzellina glacier. The comments of $\mathrm{H}$. Brecher helped to substantially improve the manuscript. F. Paul acknowledges financial support from the ESA project Glaciers_cci (4000101778/10/I-AM). This work is in memory of our friend and colleague Roberto Filippi.

Edited by: A. Kääb

\section{References}

Abermann, J., Lambrecht, A., Fischer, A., and Kuhn, M.: Quantifying changes and trends in glacier area and volume in the Austrian Ötztal Alps (1969-1997-2006), The Cryosphere, 3, 205215, doi:10.5194/tc-3-205-2009, 2009.

Abermann, J., Kuhn, M., and Fischer, A.: Climatic controls of glacier distribution and changes in Austria, Ann. Glaciol, 52/59, 83-90, 2011.

Andreassen, L. M., Paul, F., Kääb, A., and Hausberg, J. E.: Landsatderived glacier inventory for Jotunheimen, Norway, and deduced glacier changes since the 1930s, The Cryosphere, 2, 131-145, doi:10.5194/tc-2-131-2008, 2008.

Arnold, N. S., Rees, W. G., Devereux, B. J., and Amable, G. S.: Evaluating the potential of high-resolution airborne LiDAR data in glaciology, Int. J. Remote Sens., 27, 1233-1251, 2006.

Bahr, D. B., Dyurgerov, M., and Meier, M. F.: Sea-level rise from glaciers and ice caps: A lower bound, Geophys. Res. Lett., 36, L03501, doi:10.1029/2008GL036309, 2009.

Benn, D. I. and Evans, D. J. A.: Glaciers and Glaciation, Hodder Education, London, 802 pp., 2010.

Benn, D. I. and Lehmkuhl, F.: Mass balance and equilibrium-line altitudes of glaciers in high mountain environments, Quat. Int., 65/66, 15-29, 2000.

Berthier, E., Arnaud, Y., Vincent, C., and Rémy, F.: Biases of SRTM in high-mountain areas: implications for the monitoring of glacier volume changes, Geophys. Res. Lett., 33, L08502, doi:10.1029/2006GL025862 2006.

Bippus, G.: Characteristics of Summer Snow Areas on Glaciers Observed by Means of Landsat Data, Innsbruck, Univ. Diss. Austria, 2011.

Braithwaite, R. J.: Can the mass balance of a glacier be estimated from its equilibrium-line altitude?, J. Glaciol., 30, 364368, 1984.

Braithwaite, R. J. and Raper, S. C. B.: Estimating equilibrium-line altitude (ELA) from glacier inventory data, Ann. Glaciol., 50-53, 127-132, 2009.

Brock, B. W., Willis, I. C., Sharp, M. J., and Arnold, N. S.: Modelling seasonal and spatial variations in the surface energy balance of Haut Glacier d'Arolla, Switzerland, Ann. Glaciol., 31, 53-62, 2000.

Carturan, L.: Climate change effects on the cryosphere and hydrology of a high-altitude watershed, Ph.D. thesis, TeSAF - University of Padova, 187 pp., 2010.
Carturan, L. and Seppi, R.: Recent mass balance results and morphological evolution of Careser glacier (Central Alps), Geogr. Fis. Din. Quat., 30, 33-42, 2007.

Carturan, L., Cazorzi, F., and Dalla Fontana, G.: Enhanced estimation of glacier mass balance in unsampled areas by means of topographic data, Ann. Glaciol., 50, 37-46, 2009a.

Carturan, L., Dalla Fontana, G., and Cazorzi, F.: The mass balance of La Mare Glacier (Ortles-Cevedale, Italian Alps) from 2003 to 2008, Epitome, Proceedings of Geoitalia 2009 congress, Vol. 3, 298, 2009b.

Carturan, L., Dalla Fontana, G., and Borga, M.: Estimation of winter precipitation in a high-altitude catchment of the Eastern Italian Alps: validation by means of glacier mass balance observations, Geogr. Fis. Din. Quat., 35, 37-48, 2012a.

Carturan, L., Cazorzi, F., and Dalla Fontana, G.: Distributed massbalance modelling on two neighbouring glaciers in OrtlesCevedale, Italy, from 2004 to 2009, J. Glaciol., 58, 467-486, $2012 b$.

Carturan, L., Baldassi, G.A., Bondesan, A., Calligaro, S., Carton, A., Cazorzi, F., Dalla Fontana, G., Francese, R., Guarnieri, A., Milan, N., Moro, D., and Tarolli, P.: Current behavior and climatic sensitivity of the lowermost Italian glacier (Montasio Occidentale, Julian Alps), Geogr. Ann. A, 95, 79-96, 2013.

CGI (Comitato Glaciologico Italiano): Reports of the glaciological surveys, Geogr. Fis. Din. Quat., 1-34, 1978-2011.

Chueca, J., Julián, A., and López-Moreno, J. I.: Recent evolution (1981-2005) of the Maladeta glaciers, Pyrenees, Spain: extent and volume losses and their relation with climatic and topographic factors, J. Glaciol., 53, 547-557, 2007.

Citterio, M., Diolaiuti, G., Smiraglia, C., D’Agata, C., Carnielli, T., Stella, G., and Siletto, G. B.: The fluctuations of Italian glaciers during the last century: a contribution to knowledge about Alpine glacier changes, Geogr. Ann., 89, 164-182, 2007.

Clark, D. H., Clark, M. M., and Gillespie, A. R.: Debris-Covered Glaciers in the Sierra Nevada, California, and Their Implications for Snowline Reconstructions, Quat. Res., 41, 139-153, 1994.

CNR-CGI (Consiglio Nazionale delle Ricerche - Comitato Glaciologico Italiano): Catasto dei Ghiacciai Italiani, vol. 4, Torino, CGI, 1959-1962.

Cogley, J. G.: Geodetic and direct mass-balance measurements: comparison and joint analysis, Ann. Glaciol., 50, 96-100, 2009.

Cogley, J. G., Hock, R., Rasmussen, L. A., Arendt, A. A., Bauder, A., Braithwaite, R. J., Jansson, P., Kaser, G., Möller, M., Nicholson, L., and Zemp, M.: Glossary of Glacier Mass Balance and Related Terms, IHP-VII Technical Documents in Hydrology No. 86, IACS Contribution No. 2, UNESCO-IHP, Paris, 2011.

DeBeer, C. M. and Sharp, M. J.: Topographic influences on recent changes of very small glaciers in the Monashee Mountains, British Columbia, Canada, J. Glaciol., 55, 691-700, 2009.

Desio, A.: I ghiacciai del Gruppo Ortles-Cevedale, Consiglio Nazionale delle Ricerche, Comitato Glaciologico Italiano, Milano, 875 pp., 1967.

De Woul, M. and Hock, R.: Static mass-balance sensitivity of Arctic glaciers and ice caps using a degree-day approach, Ann. Glaciol., 42, 217-224, 2005.

Diolaiuti, G. A., Maragno, D., D’Agata, C., Smiraglia, C., and Bocchiola, D.: Glacier retreat and climate change: Documenting the last 50 years of Alpine glacier history from area and geometry changes of Dosdè Piazzi glaciers (Lombardy Alps, Italy), Progr. 
Phys. Geogr., 35, 161-182, 2011.

Diolaiuti, G. A., Bocchiola, D., Vagliasindi, M., D’Agata, C., and Smiraglia, C.: The 1975-2005 glacier changes in Aosta Valley (Italy) and the relations with climate evolution. Progr. Phys. Geogr., 36, 764-785, 2012.

Dubayah, R. and Rich, P. M.: Topographic solar radiation models for GIS, Int. J. Geogr. Inf. Systs., 9, 405-419, 1995.

Dyurgerov, M. B. and Meier, M. F.: Glaciers and the Changing Earth System: A 2004 Snapshot, Occas. Pap., 58, 117 pp., Institute of Arctic and Alpine Research, University of Colorado, Boulder, 2005.

Dyurgerov, M., Meier, M. F., and Bahr, D. B.: A new index of glacier area change; a tool for glacier monitoring, J. Glaciol., 55, 710-716, 2009.

Elsberg, D. H., Harrison, W. D., Echelmeyer, K. A., and Krimmel, R. M.: Quantifying the effects of climate and surface change on glacier mass balance, J. Glaciol., 47, 649-658, 2001.

Ekstrand, S.: Landsat TM-Based Forest Damage Assessment: Correction for Topographic Effects, Photogram. Eng. Rem. Sens., 62, 151-161, 1996.

Fischer, A.: Comparison of direct and geodetic mass balances on a multi-annual time scale, The Cryosphere, 5, 107-124, doi:10.5194/tc-5-107-2011, 2011.

Fountain, A. G., Hoffman, M. J., Granshaw, F., and Riedel, J.: The "benchmark glacier" concept - does it work? Lessons from the North Cascade Range, USA, Ann. Glaciol., 50, 163-168, 2009.

Frei, C. and Schär, C.: A precipitation climatology of the Alps from high-resolution rain-gauge observations, Int. J. Climatol., 18, 873-900, 1998.

Furbish, D. J. and Andrews, J. T.: The use of hypsometry to indicate long-term stability and response of valley glaciers to changes in mass transfer, J. Glaciol., 30, 199-211, 1984.

Gabrieli, J., Carturan, L., Gabrielli, P., Kehrwald, N., Turetta, C., Cozzi, G., Spolaor, A., Dinale, R., Staffler, H., Seppi, R., dalla Fontana, G., Thompson, L., and Barbante, C.: Impact of Po Valley emissions on the highest glacier of the Eastern European Alps, Atmos. Chem. Phys., 11, 8087-8102, doi:10.5194/acp-118087-2011, 2011.

Gabrielli, P., Carturan, L., Gabrieli, J., Dinale, R., Krainer, K., Hausmann, H., Davis, M., Zagorodnov, V. S., Seppi, R., Barbante, C., Dalla Fontana, G., and Thompson, L. G.: Atmospheric warming threatens the untapped glacial archive of Ortles mountain, South Tyrol, J. Glaciol., 56, 843-853, 2010.

Gabrielli, P., Barbante, C., Carturan, L., Cozzi, G., Dalla Fontana, G., Dinale, R., Dragà, G., Gabrieli, J., Kehrwald, N., Mair, V., Mikhalenko, V., Piffer, G., Rinaldi, M., Seppi, R., Spolaor, A., Thompson, L. G., and Tonidandel, D.: Discovery of cold ice in a new drilling site in the Eastern European Alps, Geogr. Fis. Din. Quat., 35, 101-105, 2012.

Gardelle, J., Berthier, E., and Arnaud Y.: Impact of resolution and radar penetration on glacier elevation changes computed from DEM differencing, J. Glaciol., 58, 419-422, 2012a.

Gardelle, J., Berthier, E., and Arnaud, Y.: Slight mass gain of Karakoram glaciers in the early 548 twenty-first century, Nat. Geosci., 5, 322-325, 2012b.

Geist, T. and Stötter, J.: Documentation of glacier surface elevation change with multi-temporal airborne laser scanner data - case study: Hintereisferner and Kesselwandferner, Tyrol, Austria. Z. Gletscherkd. Glazialgeol., Vol. 40, 2007.
Gerbaux, M., Genthon, C., Etchevers, P., Vincent, C., and Dedieu, J. P.: Surface mass balance of glaciers in the French Alps: distributed modeling and sensitivity to climate change, J. Glaciol., 51, 561-572, 2005.

Haeberli, W., Hoelzle, M., Paul, F., and Zemp, M.: Integrated monitoring of mountain glaciers as key indicators of global climate change: the European Alps, Ann. Glaciol., 46, 150-160, 2007.

Haug, T., Rolstad, C., Elvehøy, H., Jackson M., and MaalenJohansen, I.: Geodetic mass balance of the western Svartisen ice cap, Norway, in the periods 1968-1985 and 1985-2002, Ann. Glaciol., 50, 119-125, 2009.

Hoelzle, M., Haeberli, W., Dischl, M., and Peschke, W.: Secular glacier mass balances derived from cumulative glacier length changes, Global Planet. Change, 36, 295-306, 2003.

Hughes, P. D.: Response of a Montenegro glacier to extreme summer heatwaves in 2003 and 2007, Geogr. Ann., 192, 259-267, 2008.

Huss, M.: Density assumptions for converting geodetic glacier volume change to mass change, The Cryosphere, 7, 877-887, doi:10.5194/tc-7-877-2013, 2013.

Huss, M., Bauder, A., and Funk, M.: Homogenization of long-term mass balance time series, Ann. Glaciol., 50, 198-206, 2009.

Joerg, P. C., Morsdorf, F., and Zemp, M.: Uncertainty assessment of multi-temporal airborne laser scanning data: A case study at an Alpine glacier, Remote Sens. Environ., 127, 118-129, 2012.

Kaser, G., Fountain, A., and Jansson, P.: A manual for monitoring the mass balance of mountain glaciers, IHP-Technical Documents in Hydrology, 59, UNESCO, Paris, 107 pp., 2003.

Kaser, G., Cogley, J. G., Dyurgerov, M. B., Meier, M. F., and Ohmura, A.: Mass balance of glaciers and ice caps: Consensus estimates for 1961-2004, Geophys. Res. Lett., 33, 1-5, 2006.

Klok, E. J. and Oerlemans, J.: Model study of the spatial distribution of the energy and mass balance of Morteratschgletscher, Switzerland, J. Glaciol., 48, 505-518, 2002.

Knoll, C. and Kerschner, H.: A glacier inventory for South Tyrol, Italy, based on airborne laser scanner data, Ann. Glaciol., 53, 4652, 2009.

Krimmel, R. M.: Mass balance and volume of South Cascade Glacier, Washington $1958 \pm 1985$, in: edited by: Oerlemans, J., Glacier Fluctuations and Climate Change, Kluwer Academic Publishers, Dordrecht, 193-206, 1989.

Krimmel, R. M.: Analysis of difference between direct and geodetic mass balance measurements at South Cascade Glacier, Washington, Geogr. Ann., 81, 653-658, 1999.

Kuhn, M.: The mass balance of very small glaciers, Z. Gletscherkd. Glazialgeol., 31, 171-179, 1995.

Kuhn, M., Markl, G., Kaser, G., Nickus, U., Obleitner, F., and Schneider, H.: Fluctuations of climate and mass balance: different responses of two adjacent glaciers, Z. Gletscherkd. Glazialgeol., 21, 409-416, 1985.

Kuhn, M., Abermann, J., Bacher, M., and Olefs, M.: The transfer of mass-balance profiles to unmeasured glaciers, Ann. Glaciol., 50, 185-190, 2009.

Kulkarni, A. V.: Mass balance of Himalayan glaciers using AAR and ELA methods, J. Glaciol., 38, 101-104, 1992.

Lambrecht, A. and Kuhn, M.: Glacier changes in the Austrian Alps during the last three decades, derived from the new Austrian glacier inventory, Ann. Glaciol., 46, 177-184, 2007. 
Law, K. H. and Nichol, J.: Topographic correction for differential illumination effects on Ikonos satellite imagery, Proceedings of XXth ISPRS Congress: Geo-imagery bridging continents, Istanbul, Turkey, ISPRS, Vol. 35, Part 3B, 2004.

Machguth, H., Eisen, O., Paul, F., and Hoelzle, M.: Strong spatial variability of snow accumulation observed with helicopter-borne GPR on two adjacent Alpine glaciers, Geophys. Res. Lett., 33, L13503, doi:10.1029/2006GL026576 2006.

Manley, W. F.: Geospatial inventory and analysis of glaciers: a case study for the eastern Alaska Range, in: edited by: Williams Jr., R. S., and Ferrigno, J. G., Satellite image atlas of glaciers of the world. Denver, CO, United States Geological Survey, K424K439, (USGS Professional Paper 1386-K.), 2008.

Maragno, D., Diolaiuti, G., D’agata, C., Mihalcea, C., Bocchiola, D., Bianchi Janetti, E., Riccardi, A., and Smiraglia, C.: New evidence from Italy (Adamello Group, Lombardy) for analysing the ongoing decline of Alpine glaciers, Geogr. Fis. Din. Quat., 32, 31-39, 2009.

McFadden, E. M., Ramage, J., and Rodbell, D. T.: Landsat TM and ETM+ derived snowline altitudes in the Cordillera Huayhuash and Cordillera Raura, Peru, 1986-2005, The Cryosphere, 5, 419430, doi:10.5194/tc-5-419-2011, 2011.

Minnaert, M.: The reciprocity principle in lunar photometry, Astrophys. J., 93, 403-410, 1941.

Nicholson, L. and Benn, D. I.: Calculating ice melt beneath a debris layer using meteorological data, J. Glaciol., 52, 463-470, 2006.

Oerlemans, J.: Glaciers and climate change, Balkema Publishers, Lisse, 148 pp., 2001.

Oerlemans, J., Giesen, R. H. and Van den Broeke, M. R.: Retreating alpine glaciers: increased melt rates due to accumulation of dust (Vadret da Morteratsch, Switzerland), J. Glaciol., 55, 729-736, 2009.

Østrem, G. and Brugman, M.: Glacier mass-balance measurements, a manual for field and office work, N.H.R.I. Science Report, 4, 224 pp., 1991.

Patzelt, G.: The period of glacier advances in the Alps, 1965 to 1980, Z. Gletscherkd. Glazialgeol., 21, 403-407, 1985.

Paul, F.: Correspondence, Calculation of glacier elevation changes with SRTM: is there an elevation dependent bias?, J. Glaciol., 54, 945-946, 2008.

Paul, F.: The influence of changes in glacier extent and surface elevation on modeled mass balance, The Cryosphere, 4, 569-581, doi:10.5194/tc-4-569-2010, 2010.

Paul, F. and Haeberli, W.: Spatial variability of glacier elevation changes in the Swiss Alps obtained from two digital elevation models, Geophys. Res. Lett., 35, L21502, doi:10.1029/2008GL034718, 2008.

Paul, F. and Kääb, A.: Perspectives on the production of a glacier inventory from multispectral satellite data in Arctic Canada: Cumberland Peninsula, Baffin Island, Ann. Glaciol., 42, 59-66, 2005.

Paul, F. and the Glaciers_cci Team: On the accuracy of glacier outlines derived from satellite data, Geophys. Res. Abs., Vol. 14, EGU2012-12298, 2012.

Paul, F., Kääb, A., Maisch, M., Kellenberger, T. W., and Haeberli, W.: The new remote sensing-derived Swiss glacier inventory: I. Methods, Ann. Glaciol., 34, 355-361, 2002.

Paul, F., Kääb, A., Maisch, M., Kellenberger, T., and Haeberli, W.: Rapid disintegration of Alpine glaciers observed with satellite data, Geophys. Res. Lett., 31, L21402,
doi:10.1029/2004GL020816, 2004.

Paul, F., Machguth, H., and Kääb, A.: On the impact of glacier albedo under conditions of extreme glacier melt: the summer of 2003 in the Alps, EARSeL Workshop on Remote Sensing of Land Ice and Snow, Berne, 21-23.2.2005. EARSeL eProceedings, 4, 139-149, CD-ROM, 2005.

Paul, F., Kääb, A., and Haeberli, W.: Recent glacier changes in the Alps observed by satellite: Consequences for future monitoring strategies, Global Planet. Change, 56, 111-122, 2007a.

Paul, F., Maisch, M., Rothenbühler, C., Hoelzle, M., and Haeberli, W.: Calculation and visualization of future glacier extent in the Swiss Alps by means of hypsographic modelling. Global Planet. Change, 55, 343-357, $2007 \mathrm{~b}$.

Paul, F., Barry, R., Cogley, J. G., Frey, H., Haeberli, W., Ohmura, A., Ommanney, C. S. L., Raup, B., Rivera, A., and Zemp, M.: Recommendations for the compilation of glacier inventory data from digital sources, Ann. Glaciol. 50, 119-126, 2009.

Paul, F., Frey, H., and Le Bris, R.: A new glacier inventory for the European Alps from Landsat TM scenes of 2003: Challenges and results, Ann. Glaciol., 52, 144-152, 2011.

Pelto, M. S.: The current disequilibrium of North Cascade Glaciers, Hydrol. Process., 20, 769-779, 2006.

Pelto, M. S.: Forecasting temperate alpine glacier survival from accumulation zone observations, The Cryosphere, 4, 67-75, doi:10.5194/tc-4-67-2010, 2010.

Rabatel, A., Dedieu, J.-P., Thibert, E., Letréguilly, A., and Vincent, C.: 25 years (1981-2005) of equilibrium-line altitude and mass-balance reconstruction on Glacier Blanc, French Alps, using remote-sensing methods and meteorological data, J. Glaciol., 54, 307-314, 2008.

Rastner, P., Bolch, T., Mölg, N., Machguth, H., Le Bris, R., and Paul, F.: The first complete inventory of the local glaciers and ice caps on Greenland, The Cryosphere, 6, 1483-1495, doi:10.5194/tc-6-1483-2012, 2012.

Raymond, C., Neumann, T. A., Rignot, E., Echelmeyer, K., Rivera, A., and Casassa, G.: Retreat of Glaciar Tyndall, Patagonia, over the last half-century, J. Glaciol., 51, 239-247, 2005.

Rolstad, C., Haug, T., and Denby, B.: Spatially integrated geodetic glacier mass balance and its uncertainty based on geostatistical analysis: application to the western Svartisen ice cap, Norway, J. Glaciol., 55, 666-680, 2009.

Sapiano, J. J., Harrison, W. D., and Echelmeyer, K. A.: Elevation, Volume and Terminus Changes of Nine Glaciers in North America, J. Glaciol., 44, 119-135, 1998.

Thibert, E., Blanc, R., Vincent, C., and Eckert, N.: Glaciological and volumetric mass-balance measurements: error analysis over 51 years for Glacier de Sarennes, French Alps, J. Glaciol., 54, 522-532, 2008.

Törmä, M. and Härmä, P.: Topographic correction of Landsat ETMImages in Finnish Lapland, IEEE Int., 6, 3629-3631, 2003.

UNEP/WGMS: Global Glacier Changes: facts and figures, edited by: Zemp, M., Roer, I., Kääb, A., Hoelzle, M., Paul, F., and Haeberli, W., UNEP, World Glacier Monitoring Service, Zurich, Switzerland, 88 pp., 2008.

VanLooy, J. A. and Forster, R. R.: Use of historical elevation data to calculate surface-elevation and volume changes of Ha-Iltzuk Icefield, southwest British Columbia, Canada, 1970 to mid-1980s, Ann. Glaciol., 52, 109-115, 2011. 
WGMS (World Glacier Monitoring Service): World glacier inventory - Status 1988, edited by: Haeberli, W., Bösch, H., Scherler, K., Østrem, G., and Wallén, C. C., IAHS (ICSI) / UNEP / UNESCO, World Glacier Monitoring Service, Zurich, Switzerland, 458 pp., 1989.

WGMS (World Glacier Monitoring Service): Fluctuations of Glaciers 2000-2005 (Vol. IX), edited by: Haeberli, W., Zemp, M., Kääb, A., Paul, F., and Hoelzle, M., ICSU (FAGS) / IUGG (IACS) / UNEP / UNESCO / WMO, World Glacier Monitoring Service, Zurich, Switzerland, 266 pp., 2008.

WGMS (World Glacier Monitoring Service): Glacier Mass Balance Bulletin No. 9 (2006-2007), edited by: Haeberli, W., Gartner-Roer, I., Hoelzle, M., Paul, F., Zemp, M., and ICSU (WDS)/IUGG (IACS)/UNEP/UNESCO/WMO, World Glacier Monitoring Service, Zurich, Switzerland, 96 pp., 2009.

WGMS (World Glacier Monitoring Service): Glacier Mass Balance Bulletin No. 11 (2008-2009), edited by: Zemp, M., Nussbaumer, S. U., Gärtner-Roer, I., Hoelzle, M., Paul, F. and Haeberli, W., ICSU (WDS) / IUGG (IACS) / UNEP / UNESCO / WMO, World Glacier Monitoring Service, Zurich, Switzerland, 102 pp., 2011.

Zanon, G.: Venticinque anni di bilancio di massa del ghiacciaio del Careser, 1966-67/1990-91, Geogr. Fis. Din. Quat., 15, 215-220, 1992.
Zemp, M., Frauenfelder, R., Haeberli, W., and Hoelzle, M.: Worldwide glacier mass balance measurements: General trends and first results of the extraordinary year 2003 in Central Europe, Mater. Glyatsiol. Issled., 99, 3-12, 2005.

Zemp, M., Hoelzle, M., and Haeberli, W.: Distributed modelling of the regional climatic equilibrium line altitude of glaciers in the European Alps, Global Planet. Change, 56, 83-100, 2007.

Zemp, M., Paul, F., Hoelzle, M., and Haeberli, W.: Glacier fluctuations in the European Alps 1850-2000: an overview and spatiotemporal analysis of available data, in: The darkening peaks: Glacial retreat in scientific and social context, edited by: Orlove, B., Wiegandt, E., and Luckman, B., University of California Press, 152-167, 2008.

Zemp, M., Jansson, P., Holmlund, P., Gärtner-Roer, I., Koblet, T., Thee, P., and Haeberli, W.: Reanalysis of multi-temporal aerial images of Storglaciären, Sweden (1959-99) - Part 2: Comparison of glaciological and volumetric mass balances, The Cryosphere, 4, 345-357, doi:10.5194/tc-4-345-2010, 2010.

Zemp, M., Thibert, E., Huss, M., Stumm, D., Rolstad Denby, C., Nuth, C., Nussbaumer, S. U., Moholdt, G., Mercer, A., Mayer, C., Joerg, P. C., Jansson, P., Hynek, B., Fischer, A., Escher-Vetter, H., Elvehøy, H., and Andreassen, L. M.: Uncertainties and reanalysis of glacier mass balance measurements, The Cryosphere Discuss., 7, 789-839, doi:10.5194/tcd-7-789-2013, 2013. 